Article

\title{
Spatiotemporal Analysis for COVID-19 Delta Variant Using GIS-Based Air Parameter and Spatial Modeling
}

\author{
Mokhamad Nur Cahyadi ${ }^{1,2, *}$, Hepi Hapsari Handayani ${ }^{1}$ (D), IDAA Warmadewanthi ${ }^{3}$, Catur Aries Rokhmana ${ }^{4}$, \\ Soni Sunarso Sulistiawan ${ }^{5}$ (D), Christrijogo Sumartono Waloedjo ${ }^{6}$, Agus Budi Raharjo ${ }^{7}$, Endroyono ${ }^{8}$, \\ Mohamad Atok ${ }^{9}$, Shilvy Choiriyatun Navisa ${ }^{1}$, Mega Wulansari ${ }^{1}$ and Shuanggen Jin ${ }^{10}$ (D)
}

\section{check for}

updates

Citation: Cahyadi, M.N.; Handayani, H.H.; Warmadewanthi, I.; Rokhmana, C.A.; Sulistiawan, S.S.; Waloedjo, C.S.; Raharjo, A.B.; E.; Atok, M.; Navisa, S.C.; et al. Spatiotemporal Analysis for COVID-19 Delta Variant Using GIS-Based Air Parameter and Spatial Modeling. Int. J. Environ. Res. Public Health 2022, 19, 1614. https:// doi.org/10.3390/ijerph19031614

Academic Editor: Gabriella Mazzulla

Received: 28 November 2021

Accepted: 25 January 2022

Published: 30 January 2022

Publisher's Note: MDPI stays neutral with regard to jurisdictional claims in published maps and institutional affiliations.

Copyright: (C) 2022 by the authors. Licensee MDPI, Basel, Switzerland. This article is an open access article distributed under the terms and conditions of the Creative Commons Attribution (CC BY) license (https:// creativecommons.org/licenses/by/ $4.0 /)$.
1 Geomatics Engineering Department, Institut Teknologi Sepuluh Nopember, Surabaya 60111, Indonesia; hapsari@geodesy.its.ac.id (H.H.H.); shilvynavisa.18033@mhs.its.ac.id (S.C.N.); mega.18033@mhs.its.ac.id (M.W.)

2 Research Center Science Technology of Marine and Earth, Institut Teknologi Sepuluh Nopember, Surabaya 60111, Indonesia

3 Department of Environmental Engineering, Institut Teknologi Sepuluh Nopember, Surabaya 60111, Indonesia; warma@its.ac.id

4 Faculty of Engineering, Universitas Gadjah Mada, Yogyakarta 5581, Indonesia; caris@ugm.ac.id

5 Department of Anesthesiology and Reanimation, Faculty Of Medicine, Universitas Airlangga-Dr. Soetomo Hospital, Surabaya 60132, Indonesia; soni.sunarso.s@gmail.com

6 Master Program in Disaster Management, Postgraduate School, Universitas Airlangga-Dr. Soetomo Hospital, Surabaya 60132, Indonesia; christrijogo@fk.unair.ac.id

7 Department of Informatics Engineering, Institut Teknologi Sepuluh Nopember, Surabaya 60111, Indonesia; agus.budi@its.ac.id

8 Department of Electrical Engineering, Institut Teknologi Sepuluh Nopember, Surabaya 60111, Indonesia; endroyono@ee.its.ac.id

9 Department of Statistics, Institut Teknologi Sepuluh Nopember, Surabaya 60111, Indonesia; moh_atok@statistika.its.ac.id

10 Shanghai Astronomical Observatory, Chinese Academy of Sciences, Shanghai 200030, China; sgjin@shao.ac.cn

* Correspondence: cahyadi@geodesy.its.ac.id

\begin{abstract}
The coronavirus disease of 2019 (COVID-19) pandemic is currently a global challenge, with 210 countries, including Indonesia, seeking to minimize its spread. Therefore, this study aims to determine the spatiotemporal spread pattern of this virus in Surabaya using various data on confirmed cases from 28 April to 26 October 2021. It also aims to determine the relationship between pollutant parameters, such as carbon monoxide $(\mathrm{CO})$, nitrogen dioxide $\left(\mathrm{NO}_{2}\right)$, sulfur dioxide $\left(\mathrm{SO}_{2}\right)$, and ozone $\left(\mathrm{O}_{3}\right)$, as well as the government's high social restrictions policy in Java-Bali. Several methods, such as the weighted mean center, directional distribution, Getis-Ord Gi*, Moran's I, and geographically weighted regression, were used to identify the spatial spread pattern of the virus. The weighted mean center indicated that the epicenter location of the outbreak moved randomly. The directional distribution demonstrated a decrease of $21 \mathrm{~km}^{2}$ at the end of the study phase, which proved that its spread has significantly reduced in Surabaya. Meanwhile, the Getis-Ord Gi* results demonstrated that the eastern and southern parts of the study region were highly infected. Moran's I demonstrate that COVID-19 cases clustered during the spike. The geographically weighted regression model indicated a number of influence zones in the northeast, northwest, and a few in the southwest parts at the peak of $\mathrm{R}^{2}$ 0.55. The relationship between COVID-19 cases and air pollution parameters proved that people living at the outbreak's center have low pollution levels due to lockdown. Furthermore, the lockdown policy reduced $\mathrm{CO}, \mathrm{NO}_{2}, \mathrm{SO}_{2}$, and $\mathrm{O}_{3}$. In addition, increase in air pollutants; namely, $\mathrm{NO}_{2}, \mathrm{CO}, \mathrm{SO}_{2}$ and $\mathrm{O}_{3}$, was recorded after 7 weeks of lockdown implementation (started from 18 August).
\end{abstract}

Keywords: COVID-19; lockdown; spatial pattern; air pollutions 


\section{Introduction}

According to the World Health Organization (WHO), the world has been battling the spread of the coronavirus disease of 2019 or the COVID-19 pandemic since March 2020, with over 118,319 positive cases and 4292 deaths globally [1]. This virus, which causes severe respiratory problems, has a high human-to-human transmission rate and requires technology capable of analyzing and determining its spread pattern [2]. COVID-19 is caused by a severe acute respiratory syndrome coronavirus 2 (SARS-CoV-2) [2]. There are seven genera of $\mathrm{CoV}$, and SARS-CoV-2 is the seventh member of the human-infecting CoV family. SARS-CoV and MERS-CoV are responsible for pneumonia, while HCoV-229E, HCoVNL63, HCoVOC43, and HCoV-HKU1 cause relatively mild and self-limiting respiratory symptoms (common cold) [2,3]. Several efforts have been made to control the spread of this virus at the local, national, and global scale. An example is the implementation of the lockdown policies, which vary across countries and cities worldwide. However, the lockdown significantly halted all forms of transport (flights, trains, and automobiles), factories, shops, markets, and other economic and social activities.

Surabaya, the capital of East Java, has the second largest population in Indonesia with $2,874,314$ people [4] and it is the second largest city after Jakarta. It is also included as the largest metropolitan area in eastern Indonesia, which known as Gerbangkertosusila (Gresik-Bangkalan-Mojokerto-Surabaya-Sidoarjo-Lamongan) [5]. Surabaya is also the economic, commercial, industrial, and educational hub of East Java and Indonesia's eastern region [5]. The National COVID-19 Task Force (Satuan Tugas (Satgas)) revealed on 20 June that East Java had the largest number of confirmed COVID-19 deaths, with a total of 12,074 deaths. According to the Satgas of East Java, the city of Surabaya had the highest number of deaths in the province, with a total of 1382 deaths [6].

By 9 April 2020, the pandemic had spread to all provinces in Indonesia, and on 24 June 2020, over 500 cases were confirmed in almost every region [7]. According to the information posted on Lawan's website, [8] the Surabaya city area recorded 64,547 confirmed cases of COVID-19 on 26 August 2021.

Presently, the Indonesian government has made a series of policies to prevent the spread and transmission of the coronavirus from one community to another. These policies include global scale social restrictions (PSBB), micro PPKM, implementation of Java-Bali community activity restrictions (PPKM), and vaccination. Subsequently, the Indonesian Ministry of Health also issued guidelines in the subsequent development of the pandemic, which provided recommendations based on data adjustments to economic and social activities in the community through the contact-tracing mechanism. The delta variant in Indonesia was first detected in April 2021, and it is more transmissible with a greater possibility of causing severe symptoms [9]. WHO declared this variant as the fastest and most sensitive strain ever, with significant infectious strain, and capable of "picking up" the most susceptible individuals [6]. This is particularly troubling to those who have not been fully or completely vaccinated, as well as those with weak immune response systems.

A regional spatiotemporal understanding of COVID-19 is critical to provide insight into how the pandemic occurred and its continued growth and decline [10-12]. Previous studies by Purwanto et al. [10] demonstrated that it is important to determine the spatial and temporal resolution of the STC model because it affects the detailed information on the endemic/epidemic, and it is important for the hotspot analysis results. Al-Kindi et al. [11] also used the spatiotemporal assessment to determine the virus spread in Oman for 2 months. The study demonstrated that the directional pattern of COVID-19 cases has moved from the northeast to the northwest and southwest, increasing the total affected area over time. The results also demonstrated that the virus distribution is higher in the most densely populated areas. COVID-19 spatiotemporal characteristics and trends need to be considered when scheduling the reopening of activities within a state or location [12].

The virus spread can be caused by several factors, asides from the spatial variable. A study by Hassan et al. [13] demonstrated the spatial relationships between COVID-19 cases and several variables, such as air pollution, geo-meteorological, and social parameters. 
The study found a significant robust relationship between those variables in cities with significant positive cases. In addition, the correlation finding suggests that long-term bad air quality may aggravate the clinical symptoms of the disease [14].

Despite the severe impacts of lockdown on people's social life, global mobility, and economy, it temporarily improved environmental conditions. For instance, based on satellite images, many media reported a decrease in air pollution globally. This was also found in the study by $\mathrm{He}$ et al. and Cadotte $[15,16]$ conducted in some countries. Broomandi et al. [17] outlined a relationship between lockdowns and air pollution, where a decrease in road traffic and economic activities reduced the level of carbon monoxide (CO), nitrogen dioxide $\left(\mathrm{NO}_{2}\right)$, sulfur dioxide $\left(\mathrm{SO}_{2}\right)$, and particulate matter (PM10) in Tehran, irrespective of the unfavorable weather conditions. In contrast, the Ozone $\left(\mathrm{O}_{3}\right)$ and PM 2.5 concentrations increased.

However, no research has been conducted on the concurrent correlation between spatial, temporal, and air pollution. Therefore, this study aims to (1) assess the spatiotemporal pattern of COVID-19 using updated daily data recorded for 26 weeks, and (2) investigate various factors, such as confirmed cases, recovered patients, suspected cases, and air pollution ( $\mathrm{CO}, \mathrm{SO}_{2}, \mathrm{O}_{3}$, and $\mathrm{NO}$ parameters) by conducting geographically weighted regression (GWR) and ordinary least squares (OLS) regression. It aims to (3) analyze the relationship between air pollution concentrations and COVID-19 cases for 26 weeks, estimated by Sentinel-5P imagery. This research focused on the Surabaya city as one of the areas with a high death rate during the delta variant period, according to a WHO report on 23 June 2021 [6]. Therefore, the result is expected to help the Surabaya government create more appropriate policies and strategies to reduce the virus spread.

\section{Materials and Methods}

\subsection{Study Area}

Surabaya is geographically located at $7^{\circ} 9^{\prime}-7^{\circ} 21^{\prime} \mathrm{S}$ and $112^{\circ} 36^{\prime}-112^{\circ} 57^{\prime} \mathrm{E}$, with an area of 52,087 Ha. Its land and sea areas are $63.45 \%(33,048 \mathrm{Ha})$ and $36.55 \%(19,039 \mathrm{Ha})$ wide and managed by the government. The area is divided into 154 villages, as shown in Figure S1. In 2020, the total population recorded was 3,148,939 people, with Wonokusumo and Romokalisari villages constituting the largest and least, respectively [18]. Figure S2 shows the population and density of each issue in 2020.

\subsection{Dataset}

Data were collected from the official website of Satuan Tugas on COVID-19 cases in Surabaya from 28 April to 26 October 2021. This duration was selected because of the significant increase in confirmed cases at that timeframe [8]. These data were spatially linked as administrative boundaries, as shown in Table 1. All spatial data are integrated into a geodatabase file using ArcGIS (ESRI, Redlands, California). Figure 1 shows a graph of the additional COVID-19 confirmed cases for each week from 28 April to 26 October 2021 (the first week starts on 28 April and the 26th week ends on 26 October). The spatial distribution of positive cases per 100,000 populations in each village is shown in Figure 2 . This also indicates the different hotspots during a pandemic as a function of the total population from each village. Air pollution quality was also analyzed, specifically in COVID-19 hotspots, using the Sentinel-5P satellite image data to obtain an estimate of tropospheric concentrations of $\mathrm{NO}_{2}, \mathrm{SO}_{2}, \mathrm{CO}$, and $\mathrm{O}_{3}$.

\subsection{Spatial Analytic Method}

The geography information system has several tools used to determine each epidemic risk's various spatial statistics, such as distribution, hotspot, orientation, and the trajectory of spread, etc. Its techniques were used to investigate the spatial variation of the virus, visualize related information, and track pandemic hotspots spatially during the study period. Besides, it is necessary to understand the spatial variability of the incidence in relation to different environmental, sociographic, and demographic variables. It is also 
for spatio-temporal prediction of the speed and magnitude of regional transmission in the near future.

\subsubsection{Calculating Geographic Distribution}

Calculating geographic distribution (CGD) is a method used to measure the disease distribution and identify certain characteristics, such as center, direction, and orientation [11]. Epidemiologist experts use it to track and compare the changes in different places over time [19]. This study used ArcGIS 1.7 in accordance with the CGD method to analyze the spatial distribution of COVID-19 in Surabaya. CGD is used by calculating and tracking the distribution point weekly from 30 June to 24 August 2021. The first step was conducted to identify the mean center of the additional confirmed cases per week. It was performed based on the extra information related to daily cases. The second step was performed to calculate the weighted variation in the distance between each location. The directional distribution or DD (standard deviational ellipse) tool was used to track the direction and orientation of the mean center $(\mathrm{MC})$ during the study period. This tool is mainly determined by average location, dispersion (concentration), and orientation [20]. Directional distribution (standard deviational ellipse) calculates two standard deviations, one along a transformed axis of maximum concentration (y) and the other along an axis that is orthogonal to $(x)$ [21]. This ellipse provides the changing trend of COVID-19 over time.

Table 1. The dataset was obtained from BPS, BIG, OSM, and Satuan Tugas (task force) COVID-19 Surabaya.

\begin{tabular}{ccc}
\hline No & Data & Source \\
\hline 1 & Population & Badan Pusat Statistik Surabaya 2020 \\
2 & Population density & Badan Pusat Statistik Surabaya 2020 \\
& Budan Informasi Geospasial dan Open \\
3 & (city and village) & Street Map \\
4 & COVID-19 daily data (confirmed, & https://lawancovid-19.surabaya.go.id/ (30 \\
5 & Air Pollution $\left(\mathrm{NO}_{2}, \mathrm{SO}_{2}, \mathrm{O}_{3}\right.$, and $\left.\mathrm{CO}\right)$ & June 2021) \\
& & Google Earth Engine (Sentinel-5P) \\
\hline
\end{tabular}

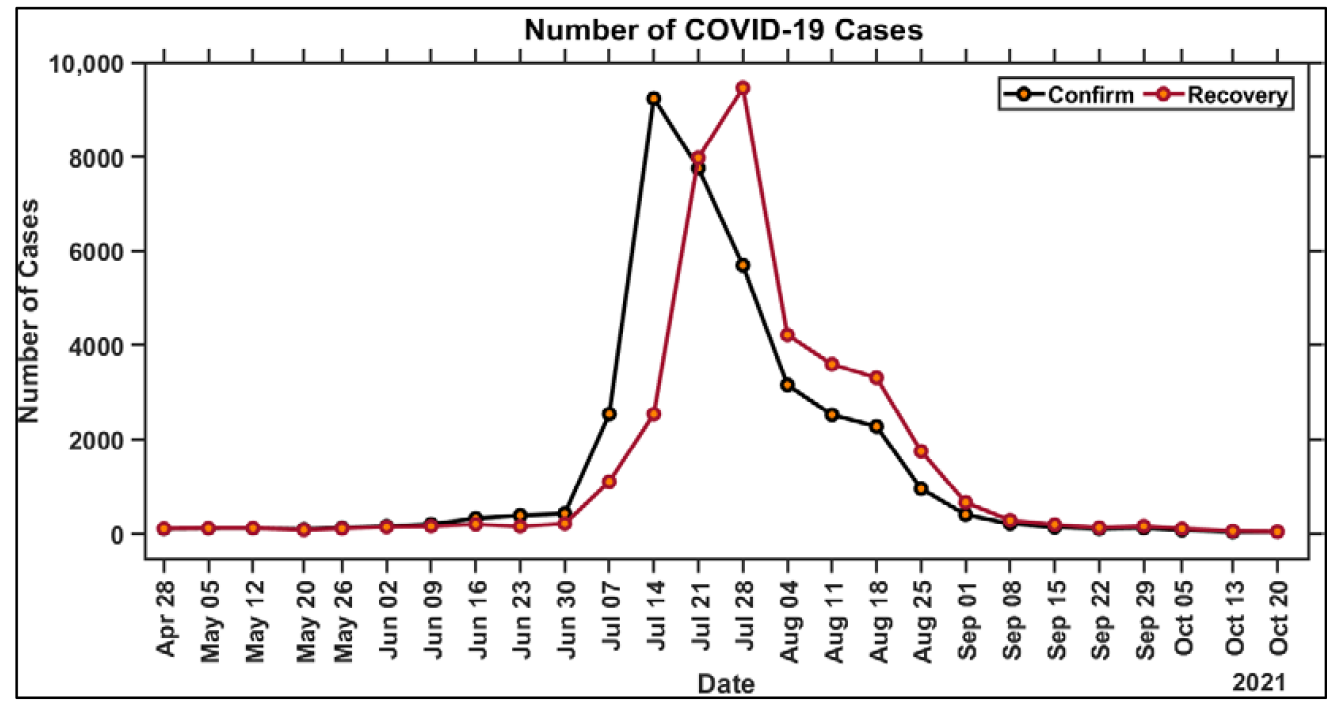

Figure 1. Graph of COVID-19 cases for 26 weeks in Surabaya. 
(a)

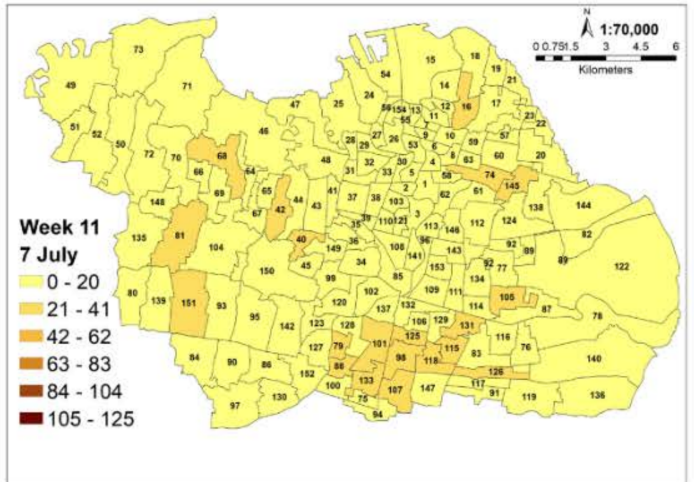

(c)

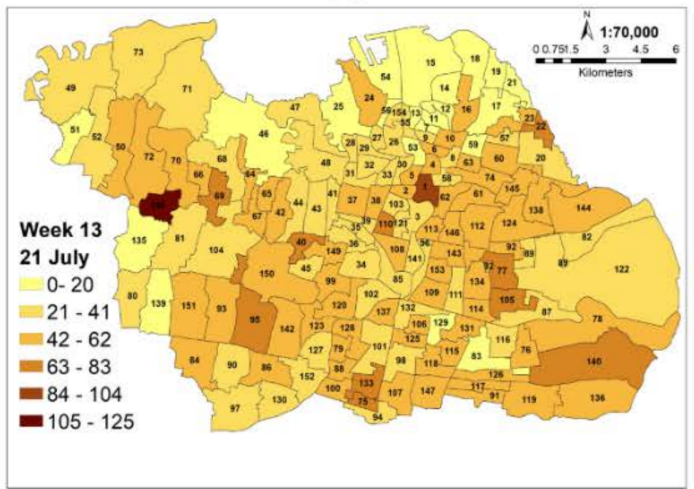

(e)

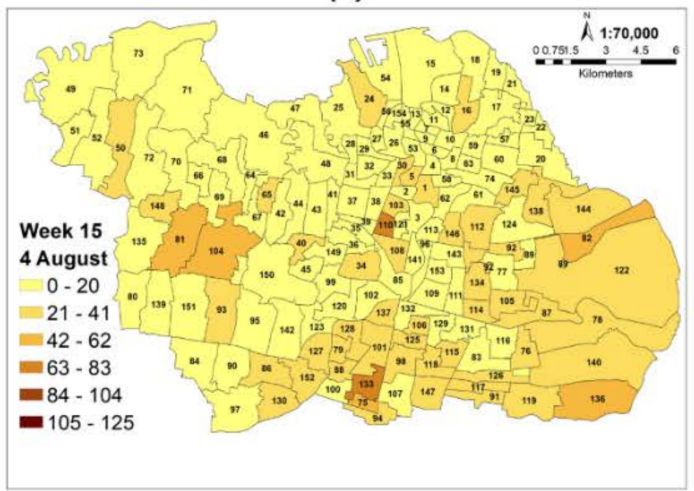

(g)

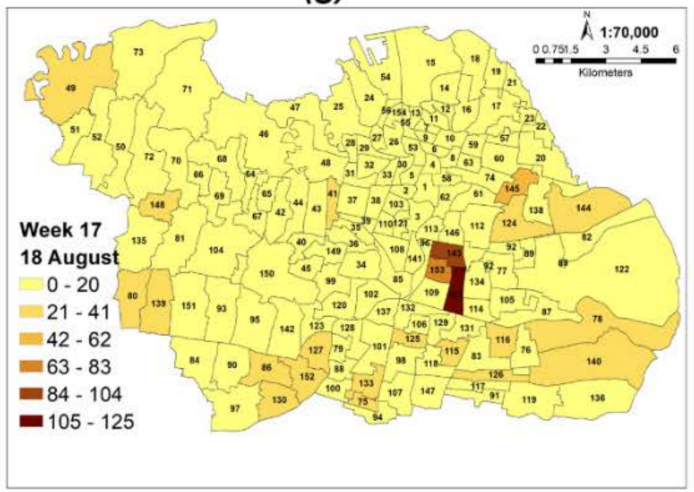

(b)

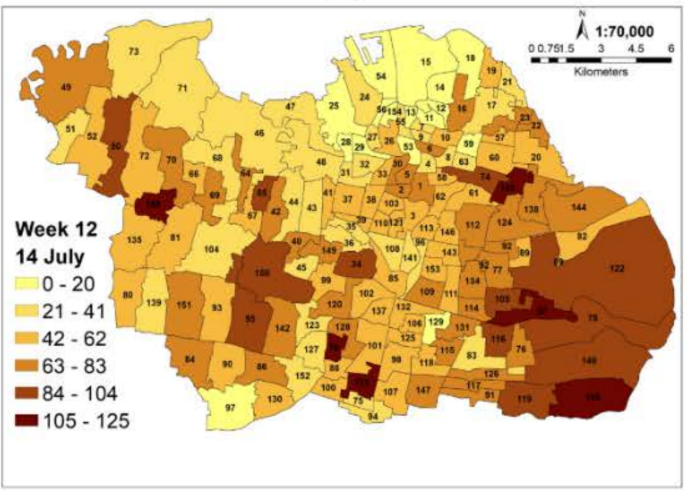

(d)

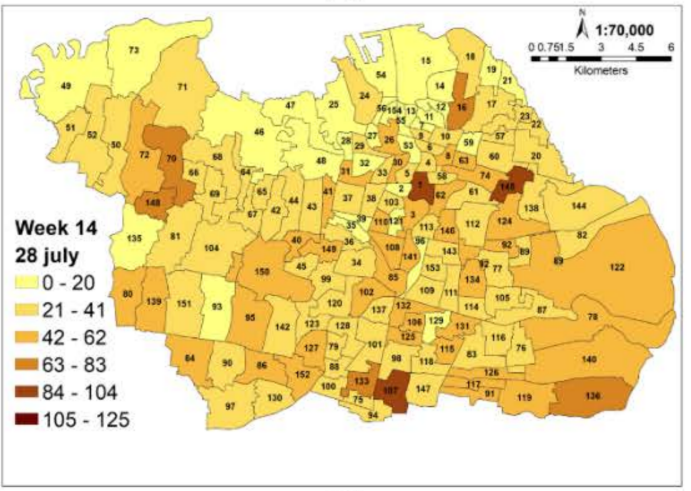

(f)

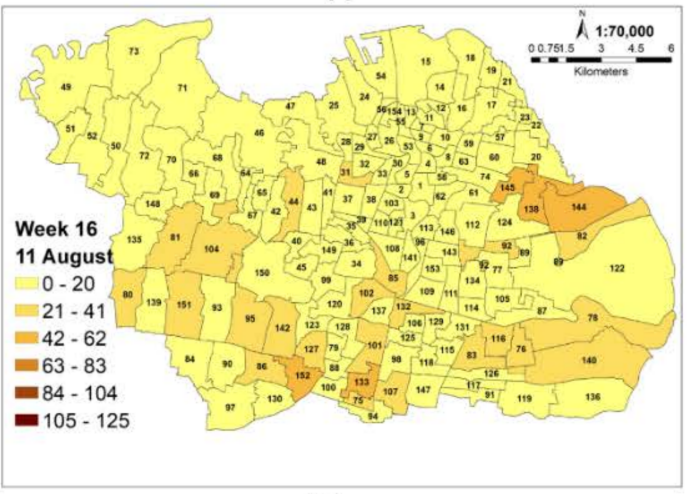

(h)

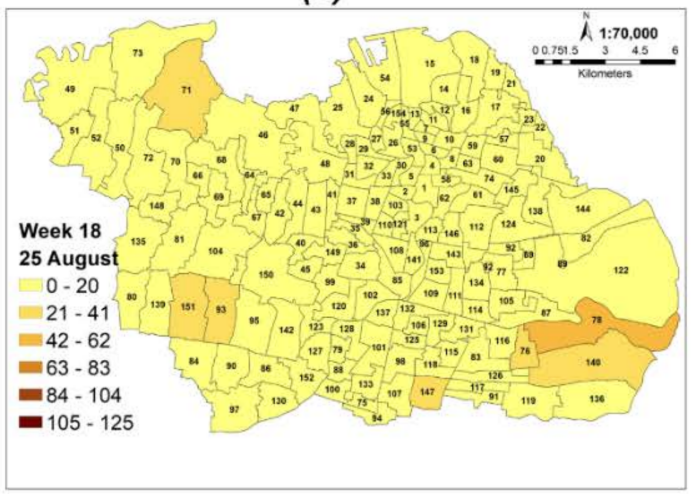

Figure 2. The peak distribution of confirmed COVID-19 cases per 100,000 populations every week in Surabaya (complete period figure for 26 weeks can be accessed in Supplementary Figure S3. (a) 11th Week (7-13 July).; (b) 12th Week (14-20 July.; (c) 13th Week (21-27 July).; (d) 14th Week (28 July-3 August).; (e) 15th Week (4-10 August).; (f) 16th Week (11-18 August).; (g) 17th Week (19-24 August).; (h) 18th Week (25-31 August). 


\subsubsection{Spatially Integrated Statistics}

Moran's I and the General G test were the geospatial statistical methods used to analyze the spatial distribution pattern of COVID-19 in this study. Both methods were used to measure the autocorrelation of spatial data and determine the spatial clustering of COVID-19 [11]. Spatial data are simply described as highly correlated, assuming the spatial variables have values close to each other and are conversely defined as independent or random data when no pattern can be identified to explain its arrangement [22].

In GIS, Moran's I autocorrelation is used to obtain positive and negative values indicating a clustering tendency and random distribution pattern [23]. However, other statistical attributes are the z-score, which quantifies the degree of deviation, such as dispersion or clustering around Moran's I scores and p-value. In this context, significant autocorrelation demonstrates that the value of a variable at a given location depends on its worth at a neighboring site and vice versa [23]. Typically, the global Moran's I value ranges from -1 to 1 and is used to denote a random pattern when close to -1 and clustering at 1 [24]. According to Prasannakumar et al. [25], Moran's I is calculated using the following equation:

$$
I=\frac{N \sum_{i} \sum_{j} W_{i j}\left(x_{i}-\bar{x}\right)\left(x_{j}-\bar{x}\right)}{\left(\sum_{i} \sum_{j} W_{i j}\right) \sum_{j}\left(x_{i}-\bar{x}\right)\left(x_{j}-\bar{x}\right)^{2}}
$$

where $N$ denotes the incidence of COVID-19, $x_{i}$ and $x_{j}$ are the variable values in different locations, $\bar{x}$ is the average of the variable, and $W_{i j}$ is the weight applied to the comparison between locations $i$ and $j$. This distance-based weight matrix is in accordance with the inverse distance between locations $I$ and $j(1 /$ dij).

Similarly, the General $G$ test is another indicator of spatial autocorrelation used to identify hotspots and local spatial clustering of COVID-19 [11]. The Getis-Ord General G high/low clustering statistic was used to denote the occurrence of clustering and whether values are strongly above or below the average. Large positive General G values close to 1 imply that clustered values are higher than average, whereas large negative General G values close to -1 suggest that they are lower than normal [26]. The Z-score is derived as the difference between the actual and expected values for General G, divided by the standard deviation of the expected randomly distributed values [27]. General G is positive, assuming there are more high values than low, and negative, supposing there are more low values than high and when both tend to cluster. According to Getis and Aldstadt [28], G is calculated using the following equation:

$$
G=\frac{\sum_{i=1}^{n} \sum_{j=1}^{n} w_{i j} x_{i} x_{j}}{\sum_{i=1}^{n} \sum_{j=1}^{n} x_{i} x_{j}}, \forall_{j} \neq i
$$

where $x_{i}$ and $x_{j}$ are the attribute values for locations $i$ and $j, w_{i j}$ denotes the weighted spatial distance between locations $i$ and $j, N$ is the number of locations, Ji depicts it, and $i$ and $j$ do not reflect the same feature. The $G$ test usually provides 4 values, namely the observed and expected General Gs, the Z score, and the $p$-value [28]. The first step in analyzing the General $\mathrm{G}$ autocorrelation is to evaluate the p-value of these statistics. Moreover, when small and large, the cases experienced spatial grouping, and random distribution, respectively. The second step involves discerning the sign of the $\mathrm{Z}$ score. The positive sign indicates that the higher values of COVID-19 cases tend to cluster in the study domain when the observed General G index is greater than expected. In contrast, the negative sign of the $\mathrm{Z}$ score implies that lesser values tend to be clustered when the General $G$ index is less than expected [29].

A hotspot analysis (Getis-Ord Gi) is commonly used to determine hotspots in GIS by providing 2 statistical values, namely $Z$ score and $p$-value. According to Huang et al. [22] both statistical values indicate the possibility of the maximum and a minimum number of COVID-19 cases to have spatial dependence or clustering. Based on the $\mathrm{z}$ score, it is evident 
that high or low incidence locations tend to be spatially clustered [22]. Furthermore, every location considered a significant COVID-19 hotspot demonstrates a high incidence [29]. The number of cases in a specific point, including its neighbors, is compared proportionally to those at all points in the location. A statically significant positive $\mathrm{Z}$ score indicates high-intensity clustering values, determined when the local count is different from the expected number. According to Huling et al. [30], a higher Z score indicates more clustering of COVID-19 incidence (hotspots). On the contrary, a negative and statistically significant smaller Z score implies more clusters of cold spots.

This study obtains the Gi statistic to analyze the spatial clustering of COVID-19 cases each week independently from April 28 to 26 October 2021. The Gi statistic is calculated using the following equation:

$$
G_{i}^{*}=\frac{\sum_{j=1}^{n} w_{i j} x_{j}-\overline{X \sum_{j=1}^{n} w_{i j}}}{s \sqrt{\frac{\left[n \sum_{j=1}^{n} w^{2}{ }_{i j}\left(\sum_{j=1}^{n} w_{i j}\right)^{2}\right]}{n-1}}}
$$

where $N$ is the incidence, $x_{i}$ and $x_{j}$ are its value in various locations, $X$ is the mean, and $w_{i j}$ is the weight applied to the comparison between locations $i$ and $j$. The distance-based weight matrix is in accordance with the inverse distance between locations $i$ and $j$, which is $1 /$ dij.

\subsubsection{GWR (Geographically Weighted Regression) Model}

Geographically weighted regression (GWR) was used to analyze the relationship between COVID-19 confirmed cases, recovered patients, and suspected cases. The different epidemic situations and medical resources most likely affect the development of a disease in a particular area. Therefore, Brunsdon et al. [31] propose a GWR model, which is an extension of the usual linear regression model by including geographic location data into the regression parameter, as shown in the following equation:

$$
y_{i}=\beta_{i 0}+\sum_{i=0}^{p} \beta_{i k} x_{i k}+\varepsilon_{i}
$$

where $y_{i}$ is the $i$-th dependent variable, $x_{i k}$ is the $k$-th independent variable of location $i, p$ is the total number, and $i 0$ is the intercept parameter at location $I$, which is the regression coefficient for the $k$-th at location and varies with the geographic location; $i$ is the error value at location $i$. The spatial weight matrix in this study is calculated using the bi-square kernel function, as shown in the following equation:

$$
w_{i j}=\left(\left(1-\left(\frac{d_{i j}}{b}\right)^{2}\right)^{2}\right.
$$

Furthermore, supposing $d_{i j}<b$, or $w_{i j}=0$, where $b$ is the bandwidth, the non-negative attenuation parameter and dij indicates the distance between $i$-th and $j$-th observation points. The bandwidth was calculated by optimizing the cross-validation's square root mean prediction error [32].

\subsubsection{Ordinary Least Squares (OLS)}

Other indicators of the occurrence of COVID-19 besides confirmed cases, recovered patients, and suspected cases are air pollutants, such as $\mathrm{O}_{3}, \mathrm{CO}, \mathrm{SO}_{2}$, and $\mathrm{NO}_{2}$, which had spatial homogeneity data. Unlike GWR, which focuses on tackling spatial heterogeneity and does not explicitly address spatial homogeneity, the ordinary least squares (OLS) is often used when the dependent and independent variables do not vary or have spatial homogeneity [33]. Therefore, the OLS method was used to determine the relationship between confirmed cases of COVID-19 and air pollutants. 
According to Hutcheson [25], ordinary least regression (OLS) is a generalized linear model performed in ArcGIS software and used to model the selected variables. This is the main technique for analyzing data and serves as the basis for several other approaches, such as the generalized linear model and ANOVA. Therefore, OLS regression is applied in various fields to the exact code of categorical variables and single or multiple variables annotations. At the basic level, the relationship between the response (y) and explanatory variables $(\mathrm{x})$ is represented using the best-fit line, which is predicted, to some extent, by $\mathrm{x}$. In assessing the model, 6 indicators supported the study feedback needed to determine whether the analysis was successful, namely model performance, significance, bias, explanation of the variables, Koenker statistics (BP), and spatial autocorrelation [34].

\subsection{Air Pollutant Concentration Due to COVID-19}

Despite the severe impacts of lockdown on social activities, global mobility, and the economy, there are reports that it temporarily improved environmental conditions. For example, it enhanced the air quality of 103 states in India, the most polluted country globally, with 21 out of the 30 world's most polluted cities [35]. Furthermore, air pollution is the largest environmental health risk, with 7 million premature deaths yearly. Moreover, more than $91 \%$ of the world's population resides in places where air quality exceeds the World Health Organization's guidelines [36].

This also causes adverse impacts on the society, economy, and the environment, including climate change. It is, in fact, the major public health, environmental, and developmental challenges of the present generation [37]. Therefore, understanding this temporary improvement in the air quality at the planetary scale provides a unique opportunity to study processes and implications of policy changes in the future. Media reports, primarily based on satellite images, concern a decrease in air pollution due to the global lockdown and some recent scientific studies in a few countries $[15,16]$.

The data from the TROPOspheric monitoring instrument (TROPOMI) sensor on the Sentinel-5 Precursor (Sentinel-5P) was collected and processed in the Google Earth Engine (Google, Mountain View, CA, USA) [38]. The European Space Agency (ESA) generated the Sentinel-5P satellite mission to bridge the data gap between the decommissioned ozone monitoring instrument (OMI) and the scanning imaging absorption spectrometer for atmospheric cartography (SCIAMACHY) onboard satellites Aura and ENVISAT, respectively, and the Sentinel-5 mission's expected launch. The primary goal of this mission is to prepare the space observations for operational monitoring of air quality, ozone, and surface UV radiation, as well as the climate, by presenting timely atmospheric composition measurements [39]. The TROPOMI sensor onboard the Sentinel-5P satellite is a high-resolution instrument that provides daily worldwide coverage from ultraviolet (UV) to shortwave infrared (SWIR) at selected spectral areas. This enables the recovery of important atmospheric elements, such as $\left(\mathrm{NO}_{2}\right),\left(\mathrm{O}_{3}\right)$, formaldehyde $\left(\mathrm{CH}_{2} \mathrm{O}\right),\left(\mathrm{SO}_{2}\right)$, methane $\left(\mathrm{CH}_{4}\right)$, carbon monoxide (CO), aerosol, and clouds. Sentinel-5P has a good signal-to-noise ratio, thus it can be functioned in low-light environments [40].

\section{Results}

\subsection{Hotspot Clustering}

COVID-19 cauterization is defined as an attribute value in each village, with red dots used to denote locations hotspots. The figures estimated by the Gi* statistic show the virus prevalence based on the weekly data from 28 April to 26 October 2021. The mean centers of the virus are weighted based on the incidence per Kelurahan for 26 weeks and marked with green dots. The DD of COVID-19 distribution in the study area was obtained from 30 June to 24 August 2021, marked by the black ellipse, and calculated using the CGD method described in Section 2.3.1.

In Figure 3, the outcome is shown weekly from 30 June to 24 August 2021. COVID-19 is at its peak during this 8-week timeframe (30 June to 24 August 2021). This finding suggests that infection rates fluctuate and that risk patterns may shift over time. The 
eastern and southern Surabaya regions with high infection rates were found based on the 8 weeks of the COVID-19 peak, 30 June to 24 August (Z scores ranged from 1.508 to 7.172 with a confidence interval of $99 \%$ ). Meanwhile, North Surabaya has been recognized as a low-infection zone ( $\mathrm{z}$-scores ranged from -4.927 to -1.318 with a confidence interval of $99 \%$ ).

(a)

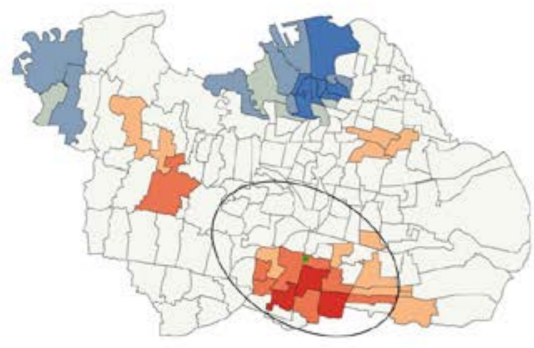

(d)

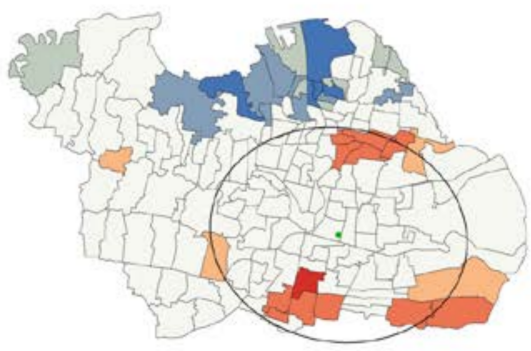

(g)

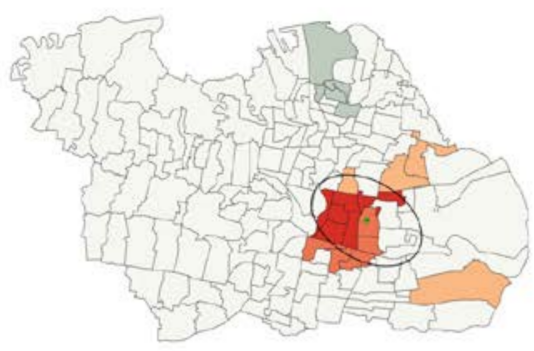

(b)

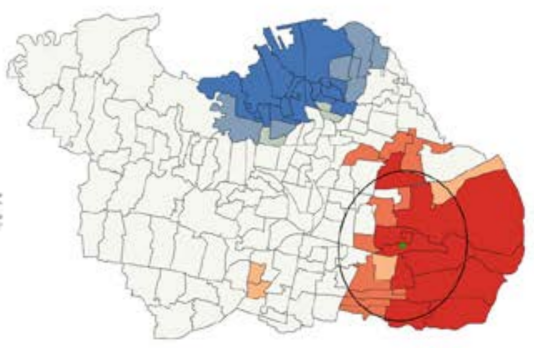

(e)

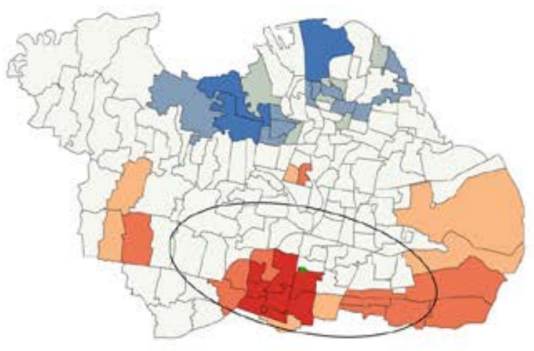

(h)

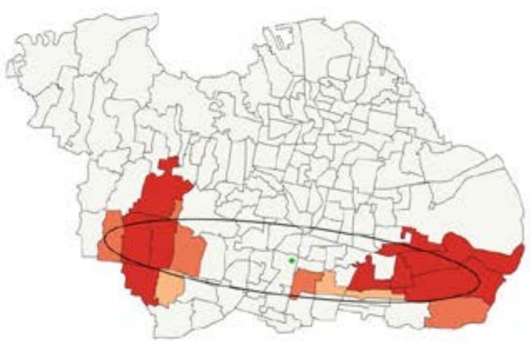

(c)

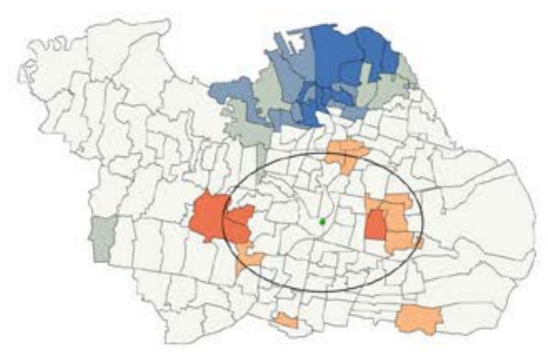

(f)

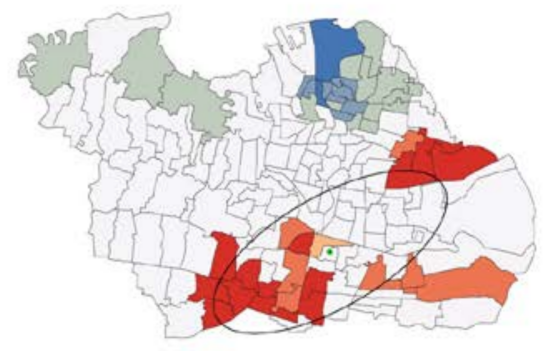

Geographic Hotspot
$=$ Cold Spot $-99 \% \mathrm{Cl}$
$=$ Cold Spot $-95 \% \mathrm{CI}$
$=$ Cold Spot $-90 \% \mathrm{Cl}$
Not Significant
$=$ Hot Spot $-90 \% \mathrm{CI}$
$=$ Hot Spot $-95 \% \mathrm{Cl}$
$=$ Hot Spot $-99 \% \mathrm{Cl}$
${ }^{*}$ Confidence Interval (Cl)

Figure 3. The peak clustering map of COVID-19 incidence along with its orientation and shift directions (complete period figure for 26 weeks can be accessed in Supplementary Materials Figure S4). (a) 11th Week (7-13 July).; (b) 12th Week (14-20 July).; (c) 13th Week (21-27 July).; (d) 14th Week (28 July-3 August).; (e) 15th Week (4-10 August).; (f) 16th Week (11-18 August).; (g)17th Week (19-24 August).; (h) 18th Week (25-31 August).

Some urban villages in the north of Surabaya, such as Gunung Anyar, Bulak, and Kembangan Utara, had fewer infections than others from 30 June to 6 July 2021. However, these areas were identified as high-risk from 7 to 13 July 2021, with z score higher than 4.06 at a hotspot of $99 \%$ confidence. Another example is the urban villages of Sawahan, Balas Klumprik, Tanah Kali Kewall, Sukolilo Baru, Gading, Jagir, and Kejawan Putih Tambak, identified as insignificant areas from 7 to 13 July 2021, which changed to high-risk areas (hotspot-99\% confidence) from 14 to 20 July 2021, as shown in Figure 3. This approach suggests that epidemiologists are able to understand clusters of disease cases assuming the spatiotemporal characteristics used are considered. 


\subsection{Weighted Mean Center (WMC)}

Figure 3 used the small green circle to illustrate the weekly changes of COVID-19 incidence in the weighted mean center (WMC) using ArcGIS software, whose purpose has been stated in Section 2.3.1. Within 26 weeks, the $\mathrm{x}$ and $\mathrm{y}$ coordinates of the average COVID-19 center in Surabaya moved many times. Overall, the results of tracking changes revealed that the center of the COVID-19 outbreak moved randomly over 26 weeks with a confidence interval $<90 \%$ at a z-score of 1.386 and a $p$-value of 0.165 . The COVID-19 average center was initially located at $691203.3693 ; 9195225.8514 \mathrm{~m}$; however, a change in the position of WMC occurred over time. For example, on 14 July 2021, WMC was located at $696771.9754 ; 9192081.5861 \mathrm{~m}$, and a week later, it shifted to $692970.8866 ; 9193668.8914 \mathrm{~m}$, approximately $3 \mathrm{~km}$ to the northwest on July 21, 2021, as shown in Table 2. Then in Figure 3, from August 4 to 18 (6th-8th week), the trend spread moved towards the northeast. This can be further consideration for policymaking, such as the enforcement of restrictions on community activities in the northeastern part of Surabaya.

Table 2. Changes in DD from center-weighted mean confirmed cases per 100,000 populations (incidence) COVID-19 over a 26 weeks study period.

\begin{tabular}{|c|c|c|c|c|c|}
\hline Week & Date & Length (km) & Width (km) & Area $\left(\mathbf{k m}^{2}\right)$ & Rotation \\
\hline 1 & 28 April 2021-4 May 2021 & 4.94367 & 1.75906 & 27.32002 & 64.34984 \\
\hline 2 & 5 May 2021-11 May 2021 & 5.96700 & 2.43495 & 45.64533 & 104.39636 \\
\hline 3 & 12 May 2021-19 May 2021 & 6.10525 & 3.35143 & 64.28118 & 95.09706 \\
\hline 4 & 20 May 2021-25 May 2021 & 5.32776 & 4.12860 & 69.10306 & 96.81598 \\
\hline 5 & 26 May 2021-1 June 2021 & 7.19094 & 2.99919 & 67.75481 & 73.92413 \\
\hline 6 & 2 June 2021-8 June 2021 & 8.20458 & 2.37165 & 61.13025 & 104.63646 \\
\hline 7 & 9 June 2021-15 June 2021 & 6.10076 & 1.34384 & 25.75626 & 49.12235 \\
\hline 8 & 16 June 2021-22 June 2021 & 10.37618 & 4.00459 & 130.54036 & 123.65276 \\
\hline 9 & 23 June 2021-29 June 2021 & 3.62656 & 0.73228 & 8.34304 & 62.94312 \\
\hline 10 & 30 June 2021-6 July 2021 & 5.08497 & 6.69721 & 106.98736 & 42.41460 \\
\hline 11 & 7 July 2021-13 July 2021 & 5.47192 & 3.65635 & 62.85471 & 120.54456 \\
\hline 12 & 14 July 2021-20 July 2021 & 3.48135 & 4.07568 & 44.57561 & 9.36094 \\
\hline 13 & 21 July 2021-27 July 2021 & 5.42577 & 3.75721 & 64.04384 & 90.09924 \\
\hline 14 & 28 July 2021-3 August 2021 & 7.00457 & 5.80578 & 127.75903 & 100.71435 \\
\hline 15 & 4 August 2021-10 August 2021 & 7.38358 & 3.36916 & 78.15178 & 102.26742 \\
\hline 16 & 11 August 2021-17 August 2021 & 7.12187 & 3.01337 & 67.42110 & 59.90758 \\
\hline 17 & 18 August 2021-24 August 2021 & 3.24594 & 2.13313 & 21.75242 & 120.95107 \\
\hline 18 & 25 August 2021-31 August 2021 & 10.26110 & 1.89992 & 61.24630 & 96.76604 \\
\hline 19 & 1 September 2021-7 September 2021 & 7.91130 & 1.57939 & 39.25427 & 93.08196 \\
\hline 20 & 8 September 2021-14 September 2021 & 7.65780 & 1.92917 & 46.41125 & 78.09290 \\
\hline 21 & 15 September 2021-21 September 2021 & 5.44430 & 1.21007 & 20.69670 & 48.95904 \\
\hline 22 & 22 September 2021-28 September 2021 & 1.98095 & 9.99348 & 62.19288 & 139.57942 \\
\hline 23 & 29 September 2021-5 October 2021 & 1.88549 & 6.52740 & 38.66456 & 33.70470 \\
\hline 24 & 4 October 2021-12 October 2021 & 0.98472 & 1.98604 & 6.14400 & 143.11851 \\
\hline 25 & 13 October 2021-19 October 2021 & 1.87011 & 4.72545 & 27.76268 & 177.96124 \\
\hline 26 & 20 October 2021-26 October 2021 & 0.96843 & 2.19412 & 6.67537 & 0.80506 \\
\hline
\end{tabular}

\subsection{Directional Distribution (DD)}

Directional Distribution (DD) analysis demonstrated that the trend of COVID-19 cases had shifted randomly from various directions in 26 weeks. Figure 3 and Figure S4 indicated that in 26 weeks, the Ketintang village and its surroundings were vulnerable to the pandemic. Although the Ketintang village is not significant, this area is a distribution center for three times in 26 weeks (as shown in Table S1) and a hotspot location with a 99\% confidence interval. The ellipse size indicates that the area is vulnerable to virus spread; therefore, it can help in policymaking. The smaller ellipse size at the end of the research period, which is on 26 October 2021, could be influenced by the policies made by the government, such as the imposition of restrictions on community activities, which came into effect again on 22 June 2021, and public order complies with government policies. The 
government's policy to impose restrictions on community activities reduced the spread of the COVID-19 delta variant.

The ellipse shape that changed size and shifted during the study period demonstrates the length and width of each ellipse's axis, rotation, and area, as indicated in Table 2. In 26 weeks, namely from 28 April to 26 October 2021, the orientation and direction of the virus spread showed a spatio-temporal trend, which affected the population. Therefore, the standard deviation of the average center of COVID-19 spread can be determined. For example, the ellipse area was $131 \mathrm{~km}^{2}, 11 \mathrm{~km}$ wide, and $14 \mathrm{~km}$ long on 30 June 2021, while on 7 July 2021, it changed into $10 \mathrm{~km}$ wide, $11 \mathrm{~km}$ long, and $92 \mathrm{~km}^{2}$, as shown in Figure 3 and Table 2.

\subsection{Spatial Clustering}

Moran's I (z-score) and General Ord G (z-score) autocorrelation are marked in blue, while Moran's $p$-value and General G p-value are in orange, as shown in Figure 4. Morans I and General Ord G are calculated using spatial integrated statistics discussed in Section 2.3.2.

a

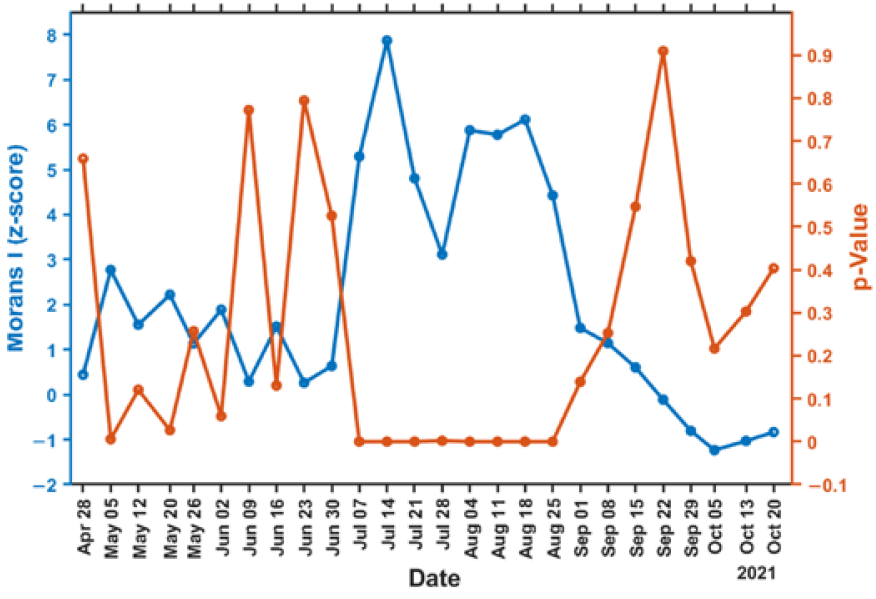

b

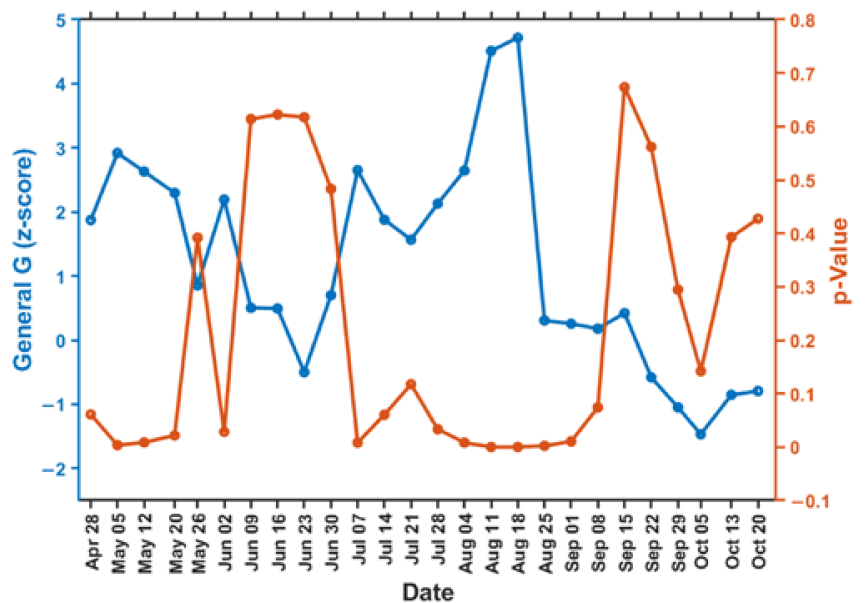

Figure 4. Spatial autocorrelation graph. (a) $p$-value and z-score Morans's I correlation; (b) $p$-value and z-score General G correlation.

The $p$-value and z-score have an inverse relationship where the $p$-value is close to 0, with a high z-score indicating a cluster pattern. Moran's I global statistics (Figure 4a) indicate that the COVID-19 cases in the dataset have a random pattern and are clustered during the spike in cases from July 7th to August 24th, 2021. The $p$-value at the peak of cases, for example between 7 July to 24 August 2021, ranged from 0-0.001, while the z-score value ranged from 3.111-7.867. This demonstrates that the Moran's I spatial autocorrelation is statistically significant with a confidence interval of $99.9 \%$. After the decline in COVID-19 cases in September, the distribution pattern of cases became random with a $p$-value of 0.139-0.909 and a z-score of $-1.235-1.478$. The more negative $z$-score value indicates a random pattern.

General G statistics (Figure 4b) demonstrate the significant height of the clustered COVID-19 incidence. The COVID-19 cases in the dataset were high-clustered several times before the strict social restrictions occurred on 22 July. At the peak of the incidence from 4 August to 14 September, the virus was high clustered with a p-value of $0-0.074$ and a z-score of 0.178 to 4.717 , at a confidence interval of $99.9 \%$. After the peak of COVID-19 incidence from 15 September to 26 October, the cases decreased, indicating a random pattern of $p$-value -0.142 to 0.673 and z-score- -1.46 to 0.421 with a confidence interval $<90 \%$. This study demonstrates the significant spatial autocorrelation between villages is positively, significantly, and spatially related distance from 7 July to 24 August 2021, as shown in Figure 4. The pattern of COVID-19 became clustered when cases spiked from 7 July to 
24 August 2021, indicating that the disease had spread less rapidly. Meanwhile, the delta variant infection decreased in Surabaya from September to October.

\subsection{Geographically Weighted Regression (GWR)}

Three parameters were used to understand the coefficient spatial distribution of independent variables in the GWR model, discussed in Section 2.3.3 and its correlation from 28 April to 26 October 2021. The parameters are population density, number of recovered patients, and suspected in the previous week. The GWR model was studied to evaluate the heterogeneity of its coefficients in space and predict the spread pattern of COVID-19 one-week ahead shown in Table 3.

Table 3. Model-fitting results derived from the geographical weighted regression (GWR) demonstrating the relationship between COVID- 19 incidence (dependent variable) and 3 independent variables, namely population density, recovery patient, and suspected cases.

\begin{tabular}{|c|c|c|c|c|c|c|c|}
\hline \multirow{2}{*}{ Week } & \multicolumn{3}{|c|}{ Estimated Coefficient } & \multicolumn{3}{|c|}{ Standard Error } & \multirow{2}{*}{$\mathbf{R}^{2}$} \\
\hline & Pop_Density & Recovery & Suspect & Pop_Density & Recovery & Suspect & \\
\hline 1 & -0.000006 & -0.00145 & 0.5942 & 0.000004 & 0.00081 & 0.0827 & 0.34 \\
\hline 2 & -0.000006 & 1.58807 & -0.3376 & 0.000005 & 0.44246 & 0.6092 & 0.08 \\
\hline 3 & -0.000006 & 1.44143 & 0.7252 & 0.000007 & 0.50798 & 1.1458 & 0.37 \\
\hline 4 & -0.000003 & 0.9533 & -0.1323 & 0.000005 & 0.46152 & 0.7389 & 0.14 \\
\hline 5 & -0.000012 & 1.76234 & 0.435 & 0.000005 & 0.50614 & 0.8879 & 0.11 \\
\hline 6 & -0.000008 & 1.62216 & -0.1898 & 0.000009 & 0.61543 & 0.3095 & 0.32 \\
\hline 7 & -0.000001 & 0.23091 & -0.2002 & 0.000007 & 0.52738 & 0.174 & 0.01 \\
\hline 8 & -0.000008 & 0.35447 & -0.0628 & 0.000009 & 0.48646 & 0.1758 & 0.01 \\
\hline 9 & 0.00001 & -0.00515 & 0.1042 & 0.000011 & 0.77978 & 0.1664 & 0.05 \\
\hline 10 & 0.000008 & 0.07483 & -0.3727 & 0.000014 & 0.89865 & 0.3131 & 0.01 \\
\hline 11 & -0.000038 & 3.56064 & -2.4404 & 0.000045 & 0.75624 & 3.2563 & 0.41 \\
\hline 12 & -0.000644 & 4.32694 & -5.6831 & 0.000179 & 0.96196 & 17.562 & 0.55 \\
\hline 13 & -0.000467 & 1.13803 & -1.3819 & 0.000115 & 0.30656 & 2.2285 & 0.30 \\
\hline 14 & -0.000347 & 1.40317 & -1.176 & 0.000143 & 0.33388 & 1.2351 & 0.46 \\
\hline 15 & -0.000306 & 0.84206 & -6.6564 & 0.000133 & 0.38841 & 13.029 & 0.43 \\
\hline 16 & -0.000228 & 1.87945 & -5.2903 & 0.00011 & 0.37022 & 12.44 & 0.72 \\
\hline 17 & -0.000129 & 3.09936 & 10.063 & 0.00015 & 0.62592 & 18.485 & 0.68 \\
\hline 18 & 0.00005 & 3.03727 & 3.4316 & 0.000038 & 0.3922 & 0.4289 & 0.89 \\
\hline 19 & -0.000056 & 3.83066 & 4.0997 & 0.00003 & 0.60965 & 0.7658 & 0.86 \\
\hline 20 & -0.000035 & 3.80442 & 4.3494 & 0.000015 & 0.51624 & 0.6211 & 0.85 \\
\hline 21 & -0.000007 & 4.4022 & 4.9018 & 0.000011 & 0.54769 & 0.6049 & 0.88 \\
\hline 22 & -0.000026 & 5.63802 & 5.2415 & 0.000014 & 0.73245 & 0.7864 & 0.94 \\
\hline 23 & -0.000014 & 4.5608 & 5.9564 & 0.000008 & 0.49729 & 0.6306 & 0.79 \\
\hline 24 & -0.000008 & 4.43153 & 4.6766 & 0.000003 & 0.38015 & 0.4695 & 0.76 \\
\hline 25 & -0.000004 & 4.37876 & 4.3851 & 0.000003 & 0.42768 & 0.5624 & 0.72 \\
\hline 26 & -0.000006 & 6.40907 & 7.2381 & 0.000004 & 0.38539 & 0.7607 & 0.96 \\
\hline
\end{tabular}

Three parameters, consisting of population density, recovered patients, and suspected cases, were used by GWR, of which population density had a negative coefficient value. The recovered patient had a positive correlation, which led to an increase in coefficient at the end of the study period. Suspected people had a negative correlation initially, which became positive in the end. Suspected cases are the most influenced variable for COVID-19 incidence, shown by the largest values between other variables. $R^{2}$ was used to understand the spatial relationship among these factors, which was weak and strong with correlation values of $34 \%$ and $96 \%$ in the three parameters.

The spatial relationship in week 12 , the virus peak, demonstrated that three parameters had a modest correlation (0.55). This model explained about $55 \%$ variation in the independent variables responsible for its incidence. The higher coefficient values of independent variables predict a good explanation for the dependent. In suspected people parameters, which are the most influenced factor, several affected zones were found in the northeast, northwest, and southwest parts, as shown in Figure 5c. In population density, 
strong influence zones were found in the north part of the city (Figure 5a). Meanwhile, in recovered patient parameters, strong influence zones were found in the northeast, east and south parts, as shown in Figure 5b.

(a)

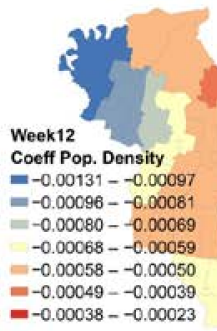

(b)

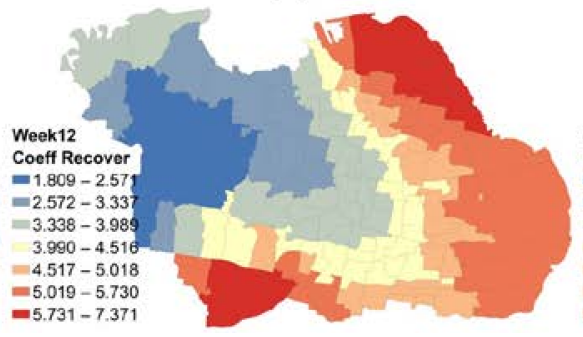

(c)

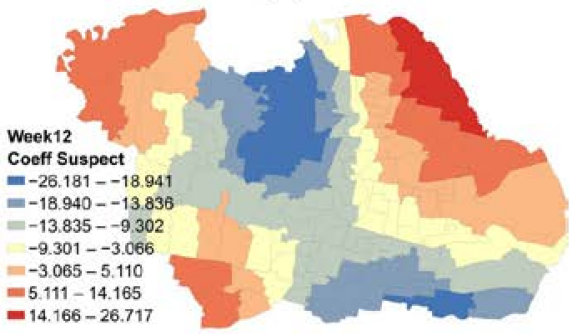

Figure 5. Spatial distribution of influence in (a) population density, (b) recovered patient, and (c) suspected cases in the peak of COVID-19.

\subsection{Air Pollution Levels Due to COVID-19 Lockdown}

This section aims to assess the air pollutant level of $\mathrm{CO}, \mathrm{NO}_{2}, \mathrm{O}_{3}$, and $\mathrm{SO}_{2}$ in the troposphere by employing remote-sensing data. Sentinel-5P image processing performed with the Google Earth Engine (GEE) resulted in maximum, minimum, and average pollution concentrations in the troposphere during the 26-week study period, as shown in Figure 6.

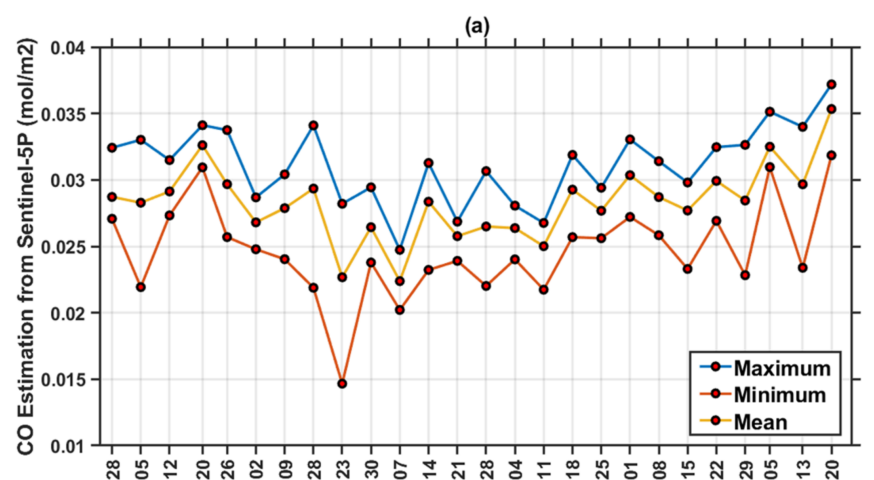

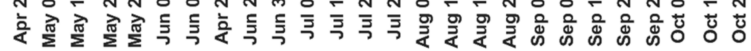

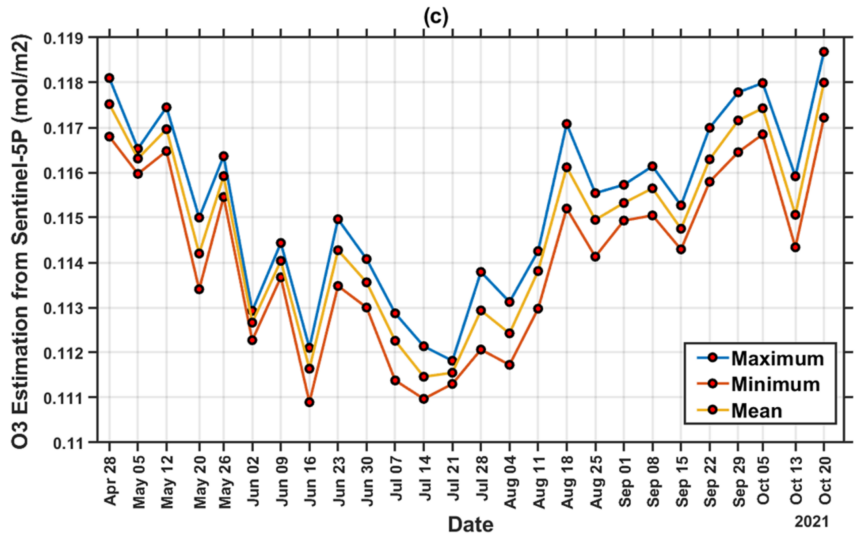

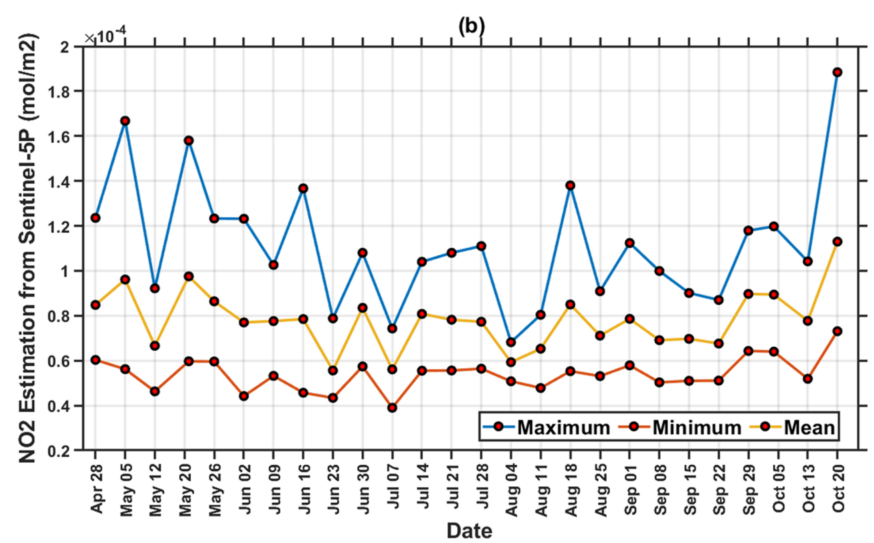

(d)

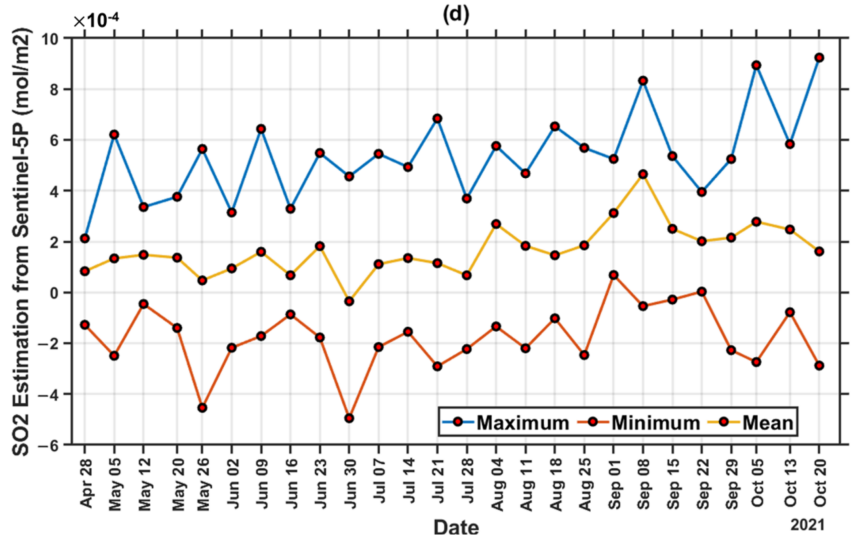

Figure 6. Concentration values of (a) Carbon Monoxide (CO); (b) Nitrogen Dioxide $\left(\mathrm{NO}_{2}\right)$; (c) Ozone $\left(\mathrm{O}_{3}\right)$; (d) Sulfur Dioxide $\left(\mathrm{SO}_{2}\right)$.

Tropospheric pollutant concentrations for 26 weeks, 6 weeks before and 7 weeks after the COVID-19 lockdown, were also mapped to observe the temporal variation through remote-sensing data, as shown in Figure 7. All parameters, such as $\mathrm{CO}, \mathrm{NO}_{2}, \mathrm{O}_{3}$, and $\mathrm{SO}_{2}$ have the most significant impact on pollution concentration when there is a lockdown policy. $\mathrm{O}_{3}$ has the highest concentration of $0.11868 \mathrm{~mol} / \mathrm{m}^{2}$ versus the other air parameters 
detected throughout the entire region. However, the concentration decreased due to the lockdown period (June 30) policy and increased after 7 weeks of lockdown implementation (started from August 18). Figure 8 shows a graph of each pollutant parameter. $\mathrm{CO}, \mathrm{O}_{3}$, and NO have the same trend. Before the lockdown until the lockdown gave a decrease trend, while $\mathrm{SO}_{2}$ gave a decreasing trend, but not too significant. The trend in all pollutant parameters increased when lockdown conditions were lifted, which was 7 weeks after the implementation of the lockdown (starting from August 18).

The highest $\mathrm{SO}_{2}$ concentration of $5.36 \times 10^{-4} \mathrm{~mol} / \mathrm{m}^{2}$ was recorded from September 15 th to 21 th and indicated no spike in COVID-19 cases. Since the lockdown conditions were lifted (back to the third level from the fourth level) in early September, it was found that the $\mathrm{SO}_{2}$ has increased considerably 7 weeks after the lockdown was implemented, which is presented in Figure 7. At the fourth level, transportation capacity was 50\%, while at the third level it was 70\%. Meanwhile, the industrial sector at PPKM level 3 may operate with a maximum capacity shift setting of $50 \%$ for each shift, while the industrial sector at the fourth level can function with a maximum capacity shift setting of $50 \%$ for each shift [41].

(a)
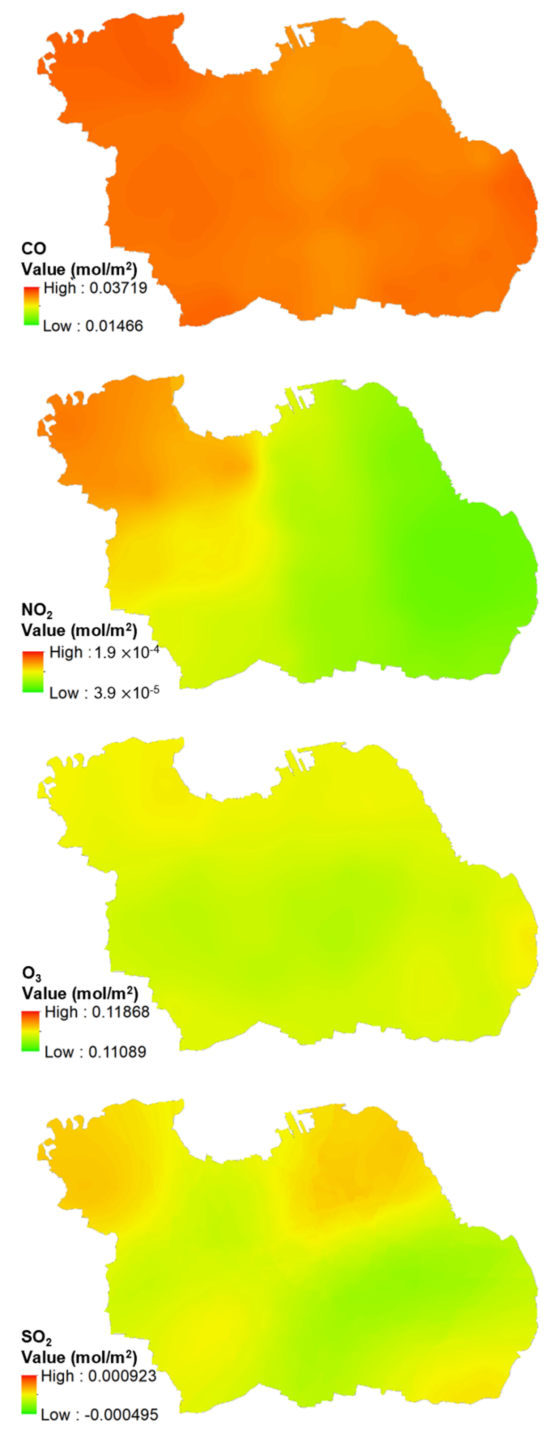

(b)
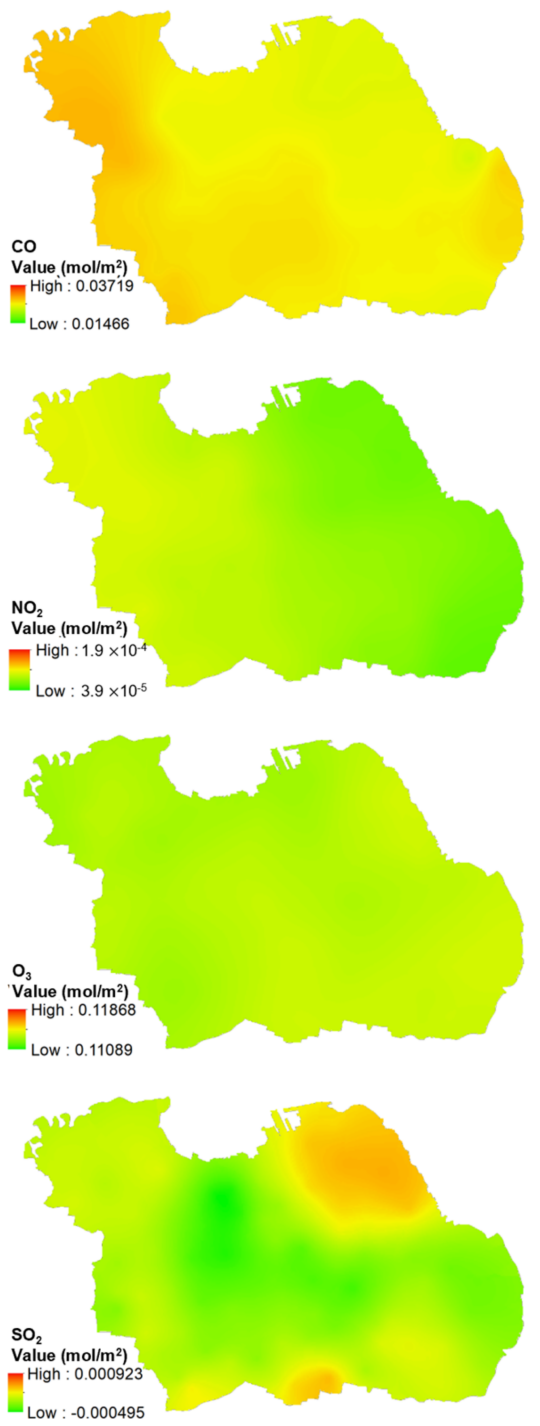

(c)
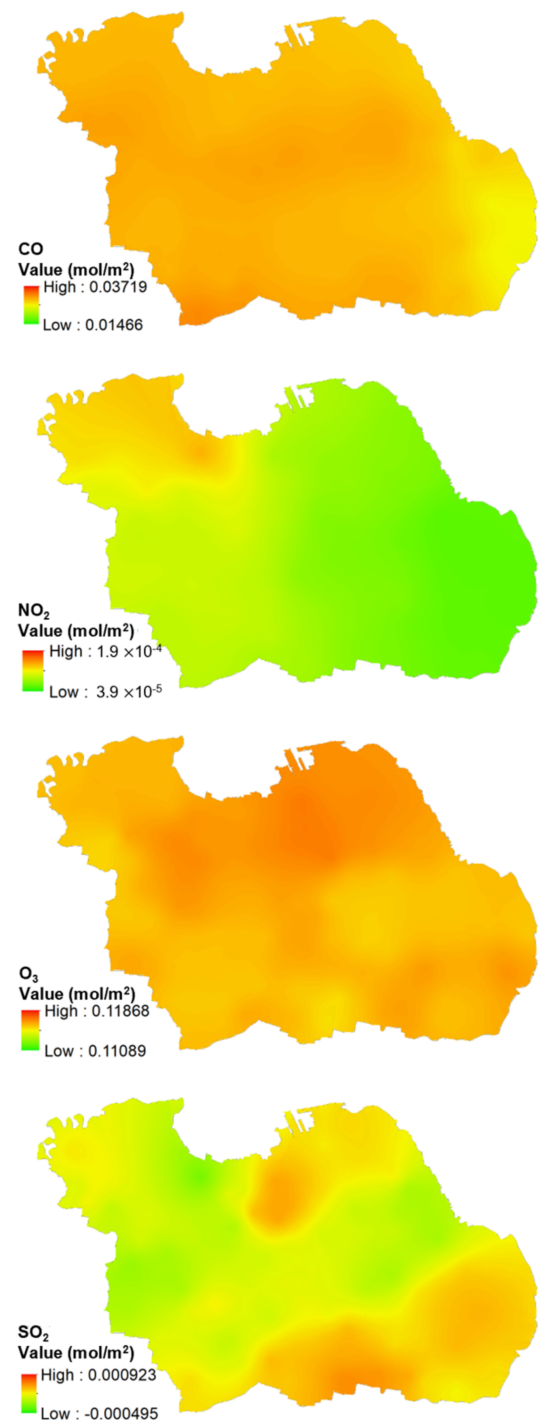

Figure 7. Air parameter concentration $\left(\mathrm{CO}, \mathrm{NO}_{2}, \mathrm{O}_{3}\right.$, and $\left.\mathrm{SO}_{2}\right)$ in Surabaya: (a) a month before, (b) next day, and (c) a month after region lockdown. 

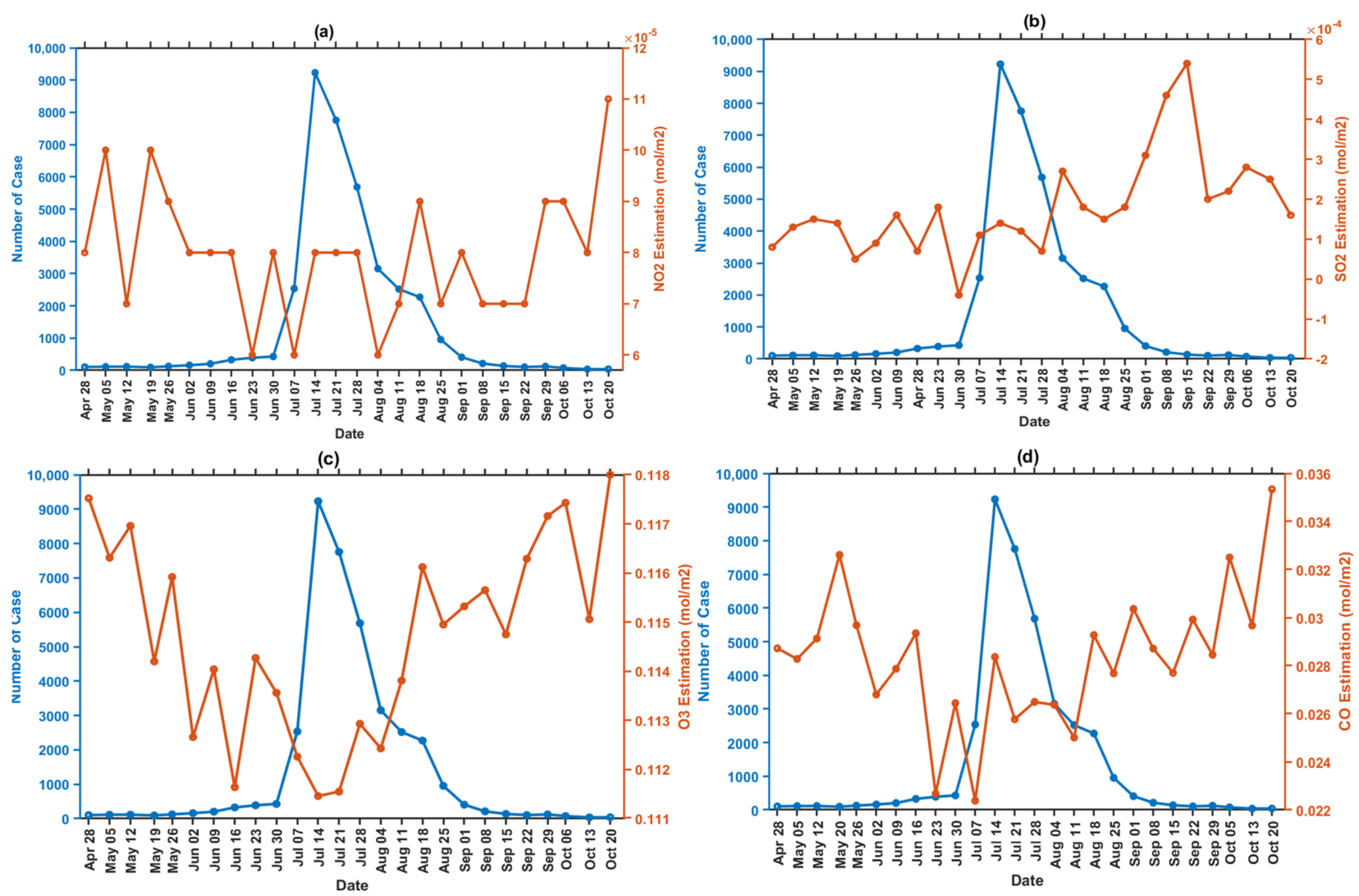

Figure 8. Graph correlation of COVID-19 incidence and air parameter based on Sentinel-5P image processing in GEE per week. (a) $\mathrm{NO}_{2}$ tropospheric concentration, (b) $\mathrm{SO}_{2}$ tropospheric concentration, (c) $\mathrm{CO}$ tropospheric concentration, and (d) $\mathrm{O}_{3}$ tropospheric concentration.

The increase was significantly observed in the southern part of Surabaya and the city center, which is the main economic activities area. The southern part of Surabaya is also the main entry point for transportation of other city residents, shown in Figure S5. Furthermore, the existing lockdown rules minimized human movement, which went back to normal after the rules were removed. Therefore, industries and transportation that use coal and motor vehicle fuel increased the sulfur dioxide concentration [42].

The highest $\mathrm{O}_{3}$ concentration occurred in the final week i.e., from October 20th to 26th, 2021 , caused by the spread of pollution from industrial activities. The lockdown has been lifted and industries have resumed its operations in this environment (high $\mathrm{O}_{3}$ period). This is in accordance with research by [43], which indicate that the increase in ozone is caused by pollution from the industry; Figure 7 demonstrates that two months after the lockdown, the northern and southeastern research areas dominated by the industry had high $\mathrm{O}_{3}$ levels with the highest $\mathrm{CO}$ concentration of $3.15 \times 10^{-2} \mathrm{~mol} / \mathrm{m}_{2}$ in the final week. Almost all areas within the center distribution of COVID-19 were contaminated by CO pollution, which led to the major cause of the distribution center.

Furthermore, an increase in air pollutants, such as $\mathrm{NO}_{2}, \mathrm{CO}, \mathrm{SO}_{2}$, and $\mathrm{O}_{3}$, was observed after 7 weeks of implementation (started from 18 August), despite a decrease in verified COVID-19 cases. Because of the decline of COVID-19 instances, the government decided to relax the lockdown policy guidelines on 24 August. This demonstrates that the presence of COVID-19 cases, the lockdown policy, and air pollution are all linked.

\subsection{Relationship between COVID-19 Incidence and Air Pollutant}

The Kriging-interpolation for Sentinel-5P imagery processed using the Google Earth Engine (GEE) was used to conduct this research. The OLS regression results for all parameters are shown in Table 4. It was positive with a statistically significant correlation 
between COVID-19 cases and air pollution during the study period. The increasing value of $\mathrm{r}$ between 14 to 28 July depicts results in accordance with the incidence data in Figure 2, where the largest $r$ value is 0.3331 . This is in accordance with the state of the highest number of COVID-19 cases in that week. These indicate that there may be a connection between positive cases and fine air pollution $\left(\mathrm{O}_{3}, \mathrm{CO}, \mathrm{NO}_{2}\right.$, and $\left.\mathrm{SO}_{2}\right)$ with the greatest effect by $\mathrm{NO}_{2}$. This relationship is indicated by the large coefficient value of -1199337.944 , obtained in 12 th week on 14 July.

Table 4. OLS regression between COVID-19 incidence and air pollution parameters.

\begin{tabular}{|c|c|c|c|c|c|c|}
\hline \multirow{2}{*}{ Week } & \multirow{2}{*}{$\mathbf{r}$} & \multirow{2}{*}{$\mathbf{R}$} & \multicolumn{4}{|c|}{ Coefficient } \\
\hline & & & $\mathrm{O}_{3}$ & $\mathrm{CO}$ & $\mathrm{SO}_{2}$ & $\mathrm{NO}_{2}$ \\
\hline 1 & 0.059 & 0.243 & 41.078 & -115.823 & 2196.099 & -8845.032 \\
\hline 2 & 0.035 & 0.188 & 183.530 & -9.763 & -908.882 & -3114.051 \\
\hline 3 & 0.006 & 0.077 & -294.505 & 21.238 & -455.957 & -976.079 \\
\hline 4 & 0.069 & 0.262 & 114.451 & 163.894 & -774.772 & -7748.330 \\
\hline 5 & 0.074 & 0.272 & -148.850 & 155.290 & 191.222 & $-16,298.614$ \\
\hline 6 & 0.084 & 0.289 & 1564.527 & -237.265 & 1601.451 & 4634.166 \\
\hline 7 & 0.015 & 0.123 & 33.325 & 119.347 & -200.555 & -2408.472 \\
\hline 8 & 0.023 & 0.151 & -381.530 & -20.501 & 843.237 & 7701.886 \\
\hline 9 & 0.011 & 0.107 & -511.875 & 26.044 & -420.067 & 7561.081 \\
\hline 10 & 0.019 & 0.137 & 1464.636 & 219.159 & 795.614 & 2537.760 \\
\hline 11 & 0.103 & 0.322 & 4849.546 & 1036.376 & 6103.810 & $-223,496.785$ \\
\hline 12 & 0.333 & 0.577 & $-31,165.367$ & 4160.563 & $88,138.945$ & $-1,199,337.944$ \\
\hline 13 & 0.123 & 0.350 & $27,404.369$ & $-13,248.590$ & -6139.623 & $-13,213.022$ \\
\hline 14 & 0.070 & 0.265 & 2107.077 & 5268.257 & $23,460.160$ & $-614,879.134$ \\
\hline 15 & 0.235 & 0.485 & 6979.684 & -4141.370 & $-43,595.925$ & $-328,846.454$ \\
\hline 16 & 0.008 & 0.092 & 1472.020 & 3265.895 & 3536.649 & $-336,158.858$ \\
\hline 17 & 0.117 & 0.341 & $-13,664.796$ & -481.837 & 5318.525 & $-106,384.125$ \\
\hline 18 & 0.054 & 0.233 & -4594.035 & 424.550 & 4146.287 & $-24,345.855$ \\
\hline 19 & 0.054 & 0.233 & -2347.285 & 276.720 & -462.544 & $-24,110.595$ \\
\hline 20 & 0.021 & 0.146 & 452.573 & -44.539 & -1317.076 & $14,171.958$ \\
\hline 21 & 0.064 & 0.253 & 396.631 & -310.415 & 370.013 & $-15,564.079$ \\
\hline 22 & 0.047 & 0.216 & 971.238 & -222.039 & -2481.582 & $36,013.294$ \\
\hline 23 & 0.028 & 0.166 & -741.397 & -27.302 & 1313.003 & 556.694 \\
\hline 24 & 0.082 & 0.286 & 442.884 & 95.709 & -204.715 & -4617.635 \\
\hline 25 & 0.040 & 0.199 & -335.258 & 23.522 & -760.015 & -636.684 \\
\hline 26 & 0.027 & 0.166 & 159.888 & 88.328 & -593.480 & 3458.184 \\
\hline
\end{tabular}

\section{Discussion}

This study was conducted using different spatiotemporal and statistical methods, such as CGD analysis, patterns, clustering, and relationships between variables, which are relevant in understanding COVID-19 spread in Surabaya from 28 April to 26 October 2021. The first approach applied involved analyzing the geographic distribution of the virus. The weighted mean center changed throughout the study phase and was denoted with a small circle highlighted in green, as shown in Figure 3. The ability to ascertain its weight is critical for tracking the value of variations associated with an area. The results obtained revealed dynamic regions that change over time due to the spread of the virus to several communities in Surabaya. According to [13], several factors can transmit viruses, including air pollution, geo-meteorological and social parameters. The high number of cases associated with its spread in Indonesia, especially in East Java, prompted the government to impose a lockdown policy. Most Indonesians infected with the virus possess the delta variant [44].

The DD trend is used to obtain the COVID-19 ellipse coincides with the affected area's population size and density features. Besides, these are partly found in the eastern and southern parts due to various government activities, residents, and schools located in these regions. Meanwhile, the northern part is a cold spot not included in the elliptical, swamp, and coastal areas, which are not dense. All these circumstances have proven that the virus 
spread is based on identifying its spatiotemporal pattern, which is higher in the most densely populated areas [12].

The Moran's I result also demonstrated a positive significant spatial autocorrelation of the virus. The spike in COVID-19 incidence affected the number of positive cases in several areas in Surabaya, as evidenced by the results of Moran's I $p$-value, which is closer to 0 . Spatial data are simply described as highly correlated, assuming likely values are spatially close to each other [45]. However, the Moran's I autocorrelation did not identify whether the distribution pattern was high or low. Therefore, this study applied the $\mathrm{G}$ test and demonstrated a significant positive correlation to validate and identify strong spatiotemporal patterns in the association between the factor and COVID-19 infection. Other factors, such as confirmed cases, the number of recovered patients a week prior, and the number of suspected people in the previous week, were also used to identify the COVID-19 pattern.

The relationship between air pollution concentrations and the number of COVID-19 cases using OLS did not demonstrate a significant pattern, as indicated in Table 4. At the end of the study period, the number of cases decreased by the ellipse area due to the narrowing level of air pollution distribution. The area in the ellipse, which is the distribution center of most COVID-19 cases, has a low level of pollution and mobilization. This is because the implementation of lockdown rules was tightened in areas with a high case rate. Areas without strict social restriction rules experience high vehicle mobilization and air pollution levels. According to Qin et al. [46], people living in regions with poor air quality are highly vulnerable to COVID-19 due to the long-term inhalation of toxic pollutants.

\section{Conclusions}

The COVID-19 data obtained in Surabaya from 28 April to 26 October 2021 used the spatial CGD, Moran's I, General-G, Gi* statistics, and the GWR models to conclude that the delta variant has a significant spatial correlation with the variables. Although Moran's global I and G statistics were used to identify strong spatial patterns of the virus regarding the variables, this approach only considers single-layer distributions at any given time. This study was able to identify which village demonstrated a high probability of infection using $\mathrm{Gi}^{*}$ hotspot and cold spot analysis. Therefore, future studies need to investigate other correlations, such as ecological, climatological, and socioeconomic variables, to effectively determine the relationship between COVID-19 hotspots, cold spots, and population density. Although the transmission is currently showing a declining trend, the epidemic situation in eastern and southern Surabaya is difficult. The spatiotemporal analysis demonstrated in this study suggests that a temporal hazard model based on weekly infection rates led to a better understanding of changes. The pollutant processing results with the number of confirmed cases of COVID-19, especially the delta variant, demonstrated a fairly strong positive correlation value of 0.577 in the third week, which was the highest. Therefore, COVID-19 is correlated with pollution levels. This study is expected to provide a useful strategy in improving the infectious disease surveillance system and control intervention in each affected area for future purposes. GIS was used to map disease incidence against several parameters, including demographics, environment, geography, and past events, to understand outbreak origins, spread patterns, and intensity, supporting the implementation of control, preventive, and surveillance measures.

There are several caveats and inherent limitations in this study. First, Sentinel-5P has a low geographical resolution compared to village areas, demanding the usage of medium resolution satellite photography. Sentinel-5, on the other hand, has a unique mission and sensor for monitoring the troposphere on a city-scale, allowing the researcher to collect data on $\mathrm{O}_{3}, \mathrm{CO}, \mathrm{SO}_{2}$, and $\mathrm{NO}_{2}$. Due to the highly dynamic nature of the disease, such as the highly contagious delta variant, it is necessary to add an analysis of the vaccination rate in each region to reduce the number of distributions and positive cases. For future studies, adding vaccination variables for each region can be added to see the rate of infection and the spread of COVID 19. 
Supplementary Materials: The following are available online at https:/ /www.mdpi.com/article/10 .3390/ijerph19031614/s1, Figure S1. Village's Administration of Surabaya as study area, Figure S2. Population Distribution of Surabaya on 2020, Figure S3. The distribution of confirmed COVID-19 cases per 100,000 populations every week in Surabaya, Figure S4. The clustering map of Covid-19 incidence along with its orientation and shift directions, Figure S5. Distribution map of Surabaya Industries. The red circle (bottom) is called the Gerbangkertosusilo area. It is the entrance area to the Surabaya and the surrounding area, includes Gresik-Bangkalan-Mojokerto-Surabaya-Sidoarjo-Lamongan, Table S1. Location of Weighted Mean Center (WMC).

Author Contributions: Conceptualization, M.N.C., A.B.R., and S.J.; methodology, H.H.H., C.A.R., S.S.S., C.S.W., S.C.N., and M.W.; software, A.B.R.; validation, I.W., S.C.N., and M.A.; formal analysis, C.A.R., S.S.S., and C.S.W.; investigation, H.H.H. and E.; resources, I.W., and M.A.; data curation, E.; writing-original draft preparation, M.N.C., C.A.R., S.C.N., and M.W.; writing-review and editing, M.N.C., S.C.N., M.W., and S.J.; visualization, C.A.R., S.S.S., C.S.W., A.B.R., and S.C.N.; supervision M.N.C., and S.J.; project administration, E.; funding acquisition, M.A. All authors have read and agreed to the published version of the manuscript.

Funding: This work was supported by Badan Riset dan Inovasi Nasional (Southeast Asia-Europe Joint Funding Scheme for Research and Innovation Program): 2243/PKS/ITS/2021; World Class Professor Program-Ministry of Higher Education, Research, and Technology, Indonesia:: 2817/E4. 1/KK.04.05/2021; Indonesian Collaborative Research Program-Program Riset Kolaborasi Indonesia (PPKI): 1328/PKS/ITS/2021.

Institutional Review Board Statement: Not applicable.

Informed Consent Statement: Not applicable.

Data Availability Statement: The Surabaya population and density data can be accessed in Badan Pusat Statistik (BPS) Surabaya 2020. The Surabaya administrative boundaries was accessed in the Badan Informasi Geospasial dan Open Street Map. The COVID-19 daily data by Satuan Tugas COVID19 Surabaya was accessed in https: / /lawancovid-19.surabaya.go.id/ (accessed on 30 June 2021).

Acknowledgments: The authors are grateful to WCP and the Southeast Asia-Europe Joint Funding Scheme for the Research and Innovation Program that funded this research.

Conflicts of Interest: The authors declared that there is no conflict of interest.

\section{References}

1. World Health Organization. Coronavirus Disease 2019 (COVID-19) Situation Report-51. Available online: https:/ /www.who. int/docs / default-source / coronaviruse/situation-reports/20200311-sitrep-51-covid-19.pdf?sfvrsn=1ba62e57_10 (accessed on 7 July 2021).

2. Li, H.; Liu, S.M.; Yu, X.H.; Tang, S.L.; Tang, C.K. Coronavirus disease 2019 (COVID-19): Current status and future perspectives. Int. J. Antimicrob. Agents 2020, 55, 105951. [CrossRef] [PubMed]

3. Li, Y.D.; Chi, W.Y.; Su, J.H.; Ferrall, L.; Hung, C.F.; Wu, T.C. Coronavirus vaccine development: From SARS and MERS to COVID-19. J. Biomed. Sci. 2020, 27, 104. [CrossRef] [PubMed]

4. BPS. Available online: https://jatim.bps.go.id/indicator/12/375/1/jumlah-penduduk-provinsi-jawa-timur.html (accessed on 10 January 2021).

5. Herdiana, A.D.; Herijanto, W. Kajian Geometrik Interchange Waru Ramp Mojokerto-Sidoarjo. J. Transp. Syst. Mater. Infrastruct. 2019, 2, 16-19. [CrossRef]

6. WHO Report. Available online: https://cdn.who.int/media/docs/default-source/searo/indonesia/covid19/external-situationreport-60_23-june-2021.pdf?sfvrsn=15d6c3ad_5? (accessed on 27 November 2021).

7. KOMPAS. Available online: https://surabaya.kompas.com/read/2020/03/18/06221591/6-pasien-positifcorona-dirawat-dirumah-sakit-surabaya-keluarga-dipantau-14?page=all (accessed on 15 November 2021).

8. Surabaya Lawan COVID-19 “Peta dan Visualisasi Data”. Available online: https://lawancovid-19.surabaya.go.id/visualsasi/ graph (accessed on 30 June 2021).

9. Delta Variant Blamed for Dramatic Covid Surge in Indonesia. Available online: https://jakartaglobe.id/news/delta-variantblamed-for-dramatic-covid-surge-in-indonesia (accessed on 28 August 2021).

10. Purwanto, P.; Utaya, S.; Handoyo, B.; Bachri, S.; Astuti, I.S.; Utomo, K.S.B.; Aldianto, Y.E. Spatiotemporal analysis of COVID19 spread with emerging hotspot analysis and space-time cube models in East Java, Indonesia. ISPRS Int. J. Geo-Inf. 2021, 10, 133. [CrossRef]

11. Al-Kindi, K.M.; Alkharusi, A.; Alshukaili, D.; Al Nasiri, N.; Al-Awadhi, T.; Charabi, Y.; El Kenawy, A.M. Spatiotemporal assessment of COVID-19 spread over Oman using GIS techniques. Earth Syst. Environ. 2020, 4, 797-811. [CrossRef] 
12. Wang, Y.; Liu, Y.; Struthers, J.; Lian, M. Spatiotemporal characteristics of the COVID-19 epidemic in the United States. Clin. Infect. Dis. 2021, 72, 643-651. [CrossRef]

13. Hassan, M.S.; Bhuiyan, M.A.H.; Tareq, F.; Bodrud-Doza, M.; Tanu, S.M.; Rabbani, K.A. Relationship between COVID-19 infection rates and air pollution, geo-meteorological, and social parameters. Environ. Monit. Assess. 2021, 193, 29. [CrossRef]

14. Naqvi, H.R.; Mutreja, G.; Shakeel, A.; Siddiqui, M.A. Spatio-temporal analysis of air quality and its relationship with major COVID-19 hotspot places in India. Remote Sens. Appl. Soc. Environ. 2021, 22, 100473. [CrossRef]

15. He, G.; Pan, Y.; Tanaka, T. COVID-19, City Lockdown, and Air Pollution: Evidence from China. Nat. Sustain. 2020, 3 , 1005-1011. [CrossRef]

16. Cadotte, M.W. Early Evidence that COVID-19 Government Policies Reduce Urban Air Pollution. EarthArXiv Prepr. 2020, 1-9. [CrossRef]

17. Broomandi, P.; Karaca, F.; Nikfal, A.; Jahanbakhshi, A.; Tamjidi, M.; Kim, J.R. Impact of COVID-19 Event on the Air Quality in Iran. Aerosol Air Qual. Res. 2020, 20, 1793-1804. [CrossRef]

18. BPS. Kecamatan Dalam Angka; BPS Kota Surabaya: Surabaya, Indonesia, 2020; p. 37.

19. Dong, W.; Yang, K.; Xu, Q.; Liu, L.; Chen, J. Spatio-temporal pattern analysis for evaluation of the spread of human infections with avian influenza A (H7N9) virus in China, 2013-2014. BMC Infect. Dis. 2017, 17, 704. [CrossRef] [PubMed]

20. Wang, B.; Shi, W.; Miao, Z. Confidence analysis of standard deviational ellipse and its extension into higher dimensional Euclidean space. PLoS ONE 2015, 10, e0118537. [CrossRef] [PubMed]

21. Carnes, A.; Ogneva-Himmelberger, Y. Temporal variations in the distribution of West Nile virus within the United States; 2000-2008. Appl. Spat. Anal. Policy 2012, 5, 211-229. [CrossRef]

22. Huang, R.; Liu, M.; Ding, Y. Spatial-temporal distribution of COVID-19 in China and its prediction: A data-driven modeling analysis. J. Infect. Dev. Count. 2020, 14, 246-253. [CrossRef] [PubMed]

23. What Is a Z-Score? What Is a $p$-Value? (ESRI). Available online: https://desktop.arcgis.com/en/arcmap/10.3/tools/spatialstatistics-toolbox/what-is-a-z-score-what-is-a-p-value.htm (accessed on 25 September 2021).

24. Adegboye, O.A.; Adekunle, A.I.; Pak, A.; Gayawan, E.; Leung, D.H.; Rojas, D.P.; Eisen, D.P. Change in outbreak epicentre and its impact on the importation risks of COVID-19 progression: A modelling study. Travel Med. Infect. Dis. 2021, 40, 101988. [CrossRef]

25. Prasannakumar, V.; Vijith, H.; Charutha, R.; Geetha, N. Spatio-temporal clustering of road accidents: GIS based analysis and assessment. Procedia-Soc. Behav. Sci. 2011, 21, 317-325. [CrossRef]

26. Mueller-Warrant, G.W.; Whittaker, G.W.; Young, W.C. GIS analysis of spatial clustering and temporal change in weeds of grass seed crops. Weed Sci. 2008, 56, 647-669. [CrossRef]

27. Mitchell, A. The ESRI Guide to GIS Analysis, Volume 2: Spatial Measurements and Statistics; ESRI Press: Redlands, CA, USA, 2005; 238p.

28. Getis, A.; Aldstadt, J. Constructing the spatial weights matrix using a local statistic. Geogr. Anal. 2004, 36, 90-104. [CrossRef]

29. Getis, A.; Ord, J.K. The analysis of spatial association by use of distance statistics. In Perspectives on Spatial Data Analysis; Springer: Berlin/Heidelberg, Germany, 2010; pp. 127-145.

30. Huling, L.; Li, H.; Ding, Z.; Hu, Z.; Chen, F.; Wang, K.; Shen, H. Spatial statistical analysis of coronavirus disease 2019 (COVID-19) in China. Geospat. Health 2020, 15. [CrossRef]

31. Brunsdon, C.; Fotheringham, A.S.; Charlton, M.E. Geographically weighted regression: A method for exploring spatial nonstationarity. Geogr. Anal. 1996, 28, 281-298. [CrossRef]

32. Fotheringham, A.S.; Brunsdon, C.; Charlton, M. Geographically Weighted Regression: The Analysis of Spatially Varying Relationships; John Wiley \& Sons: Hoboken, NJ, USA, 2003; pp. 44-46.

33. Shoff, C.; Chen, V.Y.J.; Yang, T.C. When homogeneity meets heterogeneity: The geographically weighted regression with spatial lag approach to prenatal care utilization. Geospat. Health 2014, 8, 557. [CrossRef] [PubMed]

34. Hutcheson, G.D. Ordinary least-squares regression. In The SAGE Dictionary of Quantitative Management Research; Moutinho, L., Hutcheson, G.D., Eds.; SAGE Publications: New York, NY, USA, 2011; pp. 224-228.

35. Blommberg: Singh World's Dirtiest Air Gets Cleaner after India's Lockdown. Available online: https://www.bloomberg.com/ news/articles/2020-04-07/world-s-dirtiest-air-getscleaner-after-india-s-lockdown (accessed on 9 April 2021).

36. WHO. New WHO Global Air Quality Guidelines Aim to Save Millions of Lives from Air Pollution. Air Pollution Is One of the Biggest Environmental Threats to Human Health, Alongside Climate Change. Available online: https://www.who.int/ news/item/22-09-2021-new-who-global-air-quality-guidelines-aim-to-save-millions-of-lives-from-air-pollution (accessed on 15 April 2021).

37. Haines, A.; Amann, M.; Borgford-Parnell, N.; Leonard, S.; Kuylenstierna, J.; Shindell, D. Short-lived climate pollutant mitigation and the Sustainable Development Goals. Nat. Clim. Chang. 2017, 7, 863-869. [CrossRef]

38. Gorelick, N.; Hancher, M.; Dixon, M.; Ilyushchenko, S.; Thau, D.; Moore, R. Google Earth Engine: Planetary-scale geospatial analysis for everyone. Remote Sens. Environ. 2017, 202, 18-27. [CrossRef]

39. Veefkind, J.P.; Aben, I.; McMullan, K.; Förster, H.; De Vries, J.; Otter, G.; Van Weele, M. TROPOMI on the ESA Sentinel-5 Precursor: A GMES mission for global observations of the atmospheric composition for climate, air quality and ozone layer applications. Remote Sens. Environ. 2012, 120, 70-83. [CrossRef] 
40. Voors, R.; de Vries, J.; Bhatti, I.S.; Lobb, D.; Wood, T.; van der Valk, N.; Veefkind, P. TROPOMI, the Sentinel 5 Precursor instrument for air quality and climate observations: Status of the current design. In Proceedings of the International Conference on Space Optics-ICSO 2012, Ajaccio, Corsica, France, 20 November 2017; Volume 10564.

41. Satuan Tugas Penanganan COVID-19. Available online: https://covid19.go.id/p/regulasi/instruksi-menteri-dalam-negerinomor-24-tahun-2021 (accessed on 10 January 2021).

42. Tayanc, M.E.T.E. An assessment of spatial and temporal variation of sulfur dioxide levels over Istanbul, Turkey. Environ. Pollut. 2000, 107, 61-69. [CrossRef]

43. Siciliano, B.; Dantas, G.; da Silva, C.M.; Arbilla, G. Increased ozone levels during the COVID-19 lockdown: Analysis for the city of Rio de Janeiro, Brazil. Sci. Total Environ. 2020, 737, 139765. [CrossRef]

44. Situmorang, D.D.B. Indonesia is already in a state of 'Herd Stupidity': Is it a slump? J. Public Health (Oxf. Engl.) 2021. [CrossRef]

45. Dormann, C.; McPherson, J.; Araújo, M.; Bivand, R.; Bolliger, J.; Carl, G.; Wilson, R. Methods to account for spatial autocorrelation in the analysis of species distributional data: A review. Ecography 2007, 30, 609-628. [CrossRef]

46. Qin, C.; Zhou, L.; Hu, Z.; Zhang, S.; Yang, S.; Tao, Y.; Tian, D.S. Dysregulation of immune response 658 in patients with coronavirus 2019 (COVID-19) in Wuhan, China. Clin. Infect. Dis. 2020, 71, 762-768. [CrossRef] 